\title{
Describe and Statistical Evaluation of Hydrochemical Data of Karst Phenomena in Jordan: Al-Dhaher Cave Karst Spring
}

\author{
* Iyad Ahmed Abboud \\ Associate Professor in Geochemistry, Biology Department, Collage of Sciences, Taibah University, Yanbu', Al- \\ Madina, Saudi Arabia. P.O.Box: 89 - Yanbu'
}

\begin{abstract}
Karstification in Al-Kura District, northwestern of Jordan, is distribution in the Tertiary rocks at chalky and marley-limestone unit and it forms a local shallow unconfined aquifer. This research is constructed to describe and study the hydrogeochemical of karst features and their effects on the hydrochemistry of the AlDhaher Cave. Studied samples were collected from the water of wells and springs in the study area. All types of water have a composition in milligram units for cations $\left(\mathrm{Ca}^{2+}>\mathrm{Mg}^{2+}>\left(\mathrm{Na}^{+}+\mathrm{K}^{+}\right)\right)$, and anions $\left(\mathrm{HCO}_{3}^{-}>\mathrm{Cl}^{-}\right.$ $\left.>\mathrm{NO}_{3}>\mathrm{SO}_{4}{ }^{2-}\right)$. Calcium and bicarbonate accounts approximately $80 \%$ of the total ions. The concentrations of $\mathrm{Ca}^{2+}$ and $\mathrm{Mg}^{2+}$ are strongly correlated with $\mathrm{HCO}_{3}^{-}$. The $\mathrm{rCa}^{2+} / \mathrm{rMg}^{2+}$ ratio for Al-Dhaher Spring is about 1.54, which suggests that water moves in chalky and marly limestone. Our data revealed that the main ions $\mathrm{Ca}^{2+}$, $\mathrm{Mg}^{2+}$, and $\mathrm{HCO}_{3}^{-}$have very strong correlation to spring discharge. The water is undersaturated with respect to calcite and dolomite, and the correlation of $S I_{c}$ and $S I_{d}$ to discharge is very strong ( $r=0.97$ and 0.96). Depending on comparing the coefficients variations, the type of Al-Dhaher Spring could be classified as conduit spring. The results of water analyses studies show that the aquifer system is prone to karstification and they show the impact of karstification on the chemical composition of spring waters.
\end{abstract}

Key words: karst, water chemistry, carbonate, Al-Dhaher, Jordan

\section{Introduction}

Rain and snow fall on many parts in the world in winter absorbing carbon dioxide out of air and soil, turning it into weak carbonic acid, which contribute to purity of winter water. As watercourses sink through cracks very fast, there are no surface flows in karst, which is one of its basic features, instead there are subterranean water flows dissolving rocks and expanding cracks, and in that way forming numerous caves, holes, and pits (Dreybrodt and Gabrovšek, 2003; Lauritzen, 2005).

Karstification involves dissolution of the bedrock by means of water and acids that are transported into the rock mass (Bosák, 2003; Filipponi and Jeannin, 2008). Dissolved materials are transported out of the karst, and the water-flow through the karst is driven by gravity (Kiraly, 2003; Lauritzen, 2005; Aloui and Chaabani, 2007; Papadopoulou et al., 2007; Rashed, 2012).

In the last years, many geologists groups has carried out multidisciplinary studies in geology, hydrochemistry, and microclimate at different caves located in Spain, such as: Altamira (Cañaveras et al., 1999; Papadopoulou et al., 2007), Tito Bustillo (Cañaveras et al., 2001), Candamo (Groth et al., 2001). Other different caves located in Italy such as Grotta dei Cervi (Sanchez-Moral et al., 2003) and Saint Callixtus Catacombs (Groth et al., 2001), and other karst caves such as Iskrets karst spring located in Bulgaria (Eftimi and Benderev, 2007).

Howard (1964) reported that the first stage of karst initiation could be enhanced by local acid production. Others suggested mechanisms of water penetration and initiation of karst formation, which is started in convergence of flow, addition of fresh solutions, and enhanced solutional ability (Bogli, 1964; Howard, 1966; Runnells, 1969; Dreybrodt, 1981; Bosák, 2003; Dar et al., 2011).

Jagnow (1977), Jennings (1985), Hill (1987), Polyak et al. (1998), and Dar et al. (2011) had discussed many details about geological history of Carlsbad Cavern caves. These caves have been formed in a thick, dolomite-rich carbonate rock sequence and contain abundant chemical sediments known as speleothems, which contain a variety of $\mathrm{Mg}$-bearing minerals like trioctahedral smectite in Mg-rich carbonate speleothems (Polyak and Güven, 2000). Furthermore, authigenesis of trioctahedral smectite in caves has been reported only in Bulgaria, Romania, and Turkmenistan (Hill and Forti, 1997). Abu-Jaber et al., (2006) were the first to present a detailed geological and climatological data about Al-Dhaher Cave sediments in Jordan.

Emphasis in this work is placed on studying the cave system in Al-Kura Reserve, during these main objectives:(a) To investigate, characterize the hydrochemistry of springs water and wells, and to establish some of the processes taking place within the aquifer, including the possible influence of the intensive abstractions on mineralization of the groundwater. (b) Water quality variation of Al-Kura karst springs. (c) To describe the physical aspects of the karst, (d) To study the effect of solutions passage within the joints and fractures at the 
carbonate rocks and relations with karstification phenomenon, and finally (e) To study the geological setting and providing net water in the study area on the quality of the drinking water.

\section{Study Area}

The studied area was the Berqish Reserve aquifer, which is a small karstic aquifer occupying a surface area of approximately $20 \mathrm{~km}^{2}$ at the north flank of Ajloun Dome, North of Jordan (Fig. 1a).

Limestone and marly limestone formations are found in many parts of North Jordan, mostly with deep reaching karst features. Typical of the underground regimes of such massives are small hydraulic gradients, depending on the degree of karstification. This is why groundwater flow is often observed over many distances into neighboring catchment areas. The deep wells tap the Tertiary regional aquifers; while the springs and wells discharge, perched aquifers of Quaternary age (Late Pleistocene).

\section{Physical Setting}

Al-Dhaher Cave karst, which was discovered in 1995, is located in Al-Kura District, about $25 \mathrm{~km}$ southwestern of Irbid (Fig. 1a). Al-Dhaher Cave is a structural cave mainly formed along two fault systems, one with a $\mathrm{N} 70^{\circ} \mathrm{W}$ trend and a second with a $\mathrm{N} 45^{\circ} \mathrm{E}$ trend (Abu-Jaber et al., 2006). Its area is about 4000 to $5000 \mathrm{~m}^{2}$ and catchment area is about $20 \mathrm{~km}^{2}$ and has mountain relief. The altitude of the studied area is from $600 \mathrm{~m}$ up to $950 \mathrm{~m}$. The highest part looks like a plateau tableland with longitudinal hills and smaller plateaus on them surrounding with lowest elevation.

Climate of the region is classified as a typical Mediterranean climate, with warm dry summers and cool rainy winters. According to the data from a Meteorological Department, Open Files 2007 to 2010, the mean annual precipitation is about $600 \mathrm{~mm} / \mathrm{y}$. The most intensive precipitation within the period of December, January, and February reaches up to $75 \%$ from yearly total precipitation. The snow cover at the highest altitudes in the study area in winter seasons plays a significant role in ground water recharge, and it could be available approximately to the end of the spring season while the mean annual temperature is about $15^{\circ} \mathrm{C}$.

The springs of AL-Dhaher, Ain Zubia, and Ain Zgaeg are located in the center of the Al-Dhaher Cave area, near Zubia village, and west of Kufrabeel village. In addition, two valleys flow in the study area: (1) Wadi Al Rayan: located in the west of Judita village, and it has got always outflow under the Al-Dhaher Cave and Ain Zgaeg, (2) Sahel Al Nuhair located in the north south of Kufrabeel village, near the Al-Dhaher Cave area. These wadies and springs are the main basis of erosion in this region and its basin is developed completely on karst rocks (Fig. 1b).

Hydrogeologically, the catchment area of the studied area springs are divided into two zones. The first includes outcrop of karst sediments without any river runoff. The second one is located below the first zone at lower altitude of karst phenomenon, and it consists of non-to semi, karstified rocks and some small water pathway are flowing there.

The total length of Al-Dhaher Cave is about $130 \mathrm{~m}$. The entrance is a vertical about $2 \mathrm{~m}$ deep shaft with a diameter of $1 \mathrm{~m}$. The cave consists of the main cave passage, which is typically 1 to 2 meters wide and 2 to 4 meters high. There are a number of large halls and a few branches and passages.

\section{Geology and Hydrogeology}

Geologically, the region consists mainly of Upper Cretaceous limestone, known as massive limestone unit (Bender, 1974), or Wadi Sir Formation (Masri, 1963), or A7 Formation (Wolfart, 1959). Karst processes are found out into two carbonate complexes: Wadi Sir Formation (A5/A6 and A7), consisting of massive white microcrystalline limestone, dolomitic limestone. Ruseifa Formation (B1) consisting of a thick bed of marly limestone with a thin bed of marl and chalk. The extensive fractures and karst development position and interaction between these two complexes are controlled by tectonic conditions in this part of the study area (Mikbel and Abed, 1984).

Hydrogeologically, aquifers in the most of the areas of North Jordan are divided into two major and three minor aquifers according to their water supply (El-Naser, 1991), separated from each other by a thin or extensive aquicludes. The Fuheis Formation (A3) marl aquiclude separates the Kurnub aquifer from the karstificated dolomitic limestone aquifer of Al-Hummar Formation (A4), which is considered as a minor aquifer in the study area.

The focus of the study is Wadi Sir Formation which is considered as one of the most important aquifers in northern Jordan, and the two-carbonate complex is the most important, which is discharged by Ain Zubia and Ain Zgaeg springs. This is because of the extensive fracturing and karst development which it underwent, allowing for the formation of the porosity needed to become aquifer. The overlying limestone of Upper Cretaceous carbonate complex outcrops as some spots forming some small isolated and completely discharged karst massive. They facilitate the intensive infiltration of the precipitation. Wadi Al Rayan and Sahel Al Nuhair coming from the northeastern parts of Al-Kura district and sinking in the north and south areas of the complex 
have a significant role for groundwater recharge (Fig. 1b). The groundwater flow direction is from east to west to cave spring, Ain Zubia, and Ain Zgaeg springs. The available information on the hydraulic properties of Wadi Sir Formation aquifer in the study area is very limited and is unable to give a satisfactory picture of the hydrologic situation.

The case in the study area is not different from the other karstic aquifers around the world. Wadi Sir Formation aquifer (A7) receives water directly from rainfall, and discharges it through springs; some of them can be considered as karstic springs like Al-Dhaher Cave Spring, Ain Zubia, and Ain Zgaeg. Springs in the study area display almost the same pattern of discharge fluctuation, indicating the same or similar rechargedischarge mechanisms of other springs in the region.

\section{Al-Dhaher Cave, How It Was Formed?}

The land of Al-Kura district mostly is a fully developed karst relief gradually formed as a consequence of various geological factors, including the bedrock material and tectonics, as well as climatic conditions. AlDhaher Cave karst is the most extensive and most developed karst area of the Al-Kura district (Bosák, 2003; Kempe et al., 2006).

The main classification type of cave in the study area is a solution cave formed in carbonate rocks (Sadiq and Nasir, 2002) by the action of slowly moving surface and ground water that dissolves the rock to form tunnels, irregular passages, and even large caverns along fractures, joints, faults and bedding planes (Fig. 2).

After rain on the ground, the water starts infiltration in the vadose zones to the subsurface beds, seeps into cracks and pores in the soil cover, and passing through the faults, fractures, and joints dissolution spaces got larger and would be more split and more connected (Kiraly, 2003; Screaton et al., 2004; Aloui and Chaabani, 2007; Papadopoulou et al., 2007). Eventually some of the water reaches a zone of water table where all the cracks, pores, faults, fractures, and joints in the limestone rocks are already filled with water and become dissolved and saturated in the carbonate ions (Screaton et al., 2004). This causes the formation of stalactite and stalagmite deposits downward from the ceiling and upward over the floor of the cave, respectively. The resulting of calcium bicarbonate solution is carried off in the underground drainage system (Screaton et al., 2004; Papadopoulou et al., 2007).

Stalactite and stalagmite in Al-Dhaher Cave both grow as a concentric layers and as a cylinder shape and may reach lengths to several meters with more than one meter of base diameter (Fig. 3). Curtain shape is formed of a wavy or folded sheet hanging from the upper roof or wall of a cave to about 2 to 3 meters long and about 1 to 1.5 meters width. Curtain developed where the feed water trickles down an inclined wall (Fig. 4). Some shallow and small caves in the study area are distributed near and around the Al-Dhaher Cave and formed near the earth's surface -above the saturated zone- where the water moved downward through the cracks, pore spaces, joints, and fractures.

\section{Methodology}

The springs in the study area were examined continuously over three consecutive years, in order to identify the chemical water during different seasons of the year (summer and winter). A number of graphs were constructed in order to clarify the correlation between the concentration of different ions in the water, and linking it with the ability of discharge water springs during the different seasons to determine the most important factors affecting corrosion of carbonate rocks through time, and thus build the karst caves in the region. Particular attention was paid also to calcite and dolomite equilibrium of spring's water.

Samples were collected during 2007-2010 as presented in Tables 1 to 4. All study samples of springs were taken in the only available way at the spring's pipe mouth.

Fifty-five water samples were collected, 20 samples from 8 different wells distributed through the study area, and 35 samples were collected as followed: 5 samples from Al-Dhaher Cave Spring, 15 samples from Ain Zubia, and 15 samples from Ain Zgaeg. The last two springs flow near Al-Dhaher Cave. Ain Zubia connected with Al-Dhaher Cave Spring along hydrogeological aquifer, supplying it with water during all of the spent time.

Temperature, electrical conductivity, and $\mathrm{pH}$ were measured using standard electrodes. The major cations $\left(\mathrm{Ca}^{2+}, \mathrm{Mg}^{2+}, \mathrm{Na}^{+}, \mathrm{K}^{+}\right)$were analyzed using Atomic Absorption Spectroscopy (AAS, model Philips SP 9PYE Unicam Spectrophotometer), anions such as bicarbonate $\left(\mathrm{HCO}_{3}^{-}\right)$and chloride $\left(\mathrm{Cl}^{-}\right)$were analyzed using standard titration techniques, while sulfate $\left(\mathrm{SO}_{4}{ }^{2-}\right)$, and nitrate $\left(\mathrm{NO}_{3}^{-}, \mathrm{NO}_{2}^{-}\right)$were measured using spectrophotometer techniques.

From the results of the chemical analyses, ionic strength $(I)$, calcite saturation index $\left(\mathrm{SI}_{\mathrm{c}}\right)$, dolomite saturation index $\left(\mathrm{SI}_{\mathrm{d}}\right), \mathrm{rCa}^{2+}, \mathrm{rMg}^{2+}, \mathrm{rCa}^{2+}+\mathrm{rMg}^{2+}$, and $\mathrm{rCa}^{2+} / \mathrm{rMg}^{2+}(\mathrm{r}=\mathrm{mg} / \mathrm{l}$ of ion/equivalent weight of ion; equivalent weight of ion $=$ atomic weight of ion/ valence of ion) were calculated (Garrels and Christ, 1965; Thrailkill, 1976). $\mathrm{SI}_{\mathrm{c}}$ and $\mathrm{SI}_{\mathrm{d}}$ are defined as follows:

$\mathrm{SI}_{\mathrm{c}}=\left(\mathrm{Ca}^{2+}\right)$ 
$\mathrm{SI}_{\mathrm{d}}=\left(\mathrm{Ca}^{2+}\right) \cdot\left(\mathrm{Mg}^{2+}\right) \cdot\left(\mathrm{CO}_{3}{ }^{2-}\right)_{2} / \mathrm{Kd}$

Where the brackets indicate activities of the ions; $\mathrm{Kc}$ and $\mathrm{Kd}$ are the respective equilibrium constants of calcite $=-8.48$ and dolomite $=-16.54$, respectively.

Ionic strength $(\boldsymbol{I})$ is then calculated. Once $\boldsymbol{I}$ is known, the activity of ions $\mathrm{Ca}^{2+}, \mathrm{Mg}^{2+}$ and $\mathrm{CO}_{3}{ }^{2-}$ are calculated using the Debye-Hückel equation (Garrels and Christ, 1965) as follows:

$I=1 / 2 \sum \mathbf{m}_{\mathrm{i}} \mathbf{z}_{\mathbf{i}}^{2}$

Where $\boldsymbol{I}$ is the ionic strength of the solution, the summation sign $\left(\sum\right)$ means that the contributions from all ions in solution, $\mathbf{m}_{\mathbf{i}}$ is the concentration of the ion and calculated the concentration of $\mathbf{m}_{\mathbf{i}}$ in mole/L, and finally $\mathbf{z}_{\mathbf{i}}$ is the charge on the particular ion.

The values of the equilibrium constants used in this study are those given by Langmuir (1971), Thrailkill (1976), and Drever (1983). The most important uncertainty among measured values is in the pH. The uncertainty of $\mathrm{pH}$ strongly depends on changes in experimental details and on the $\mathrm{pH}$ value itself. The uncertainty is the lowest near the isopotential point and in the center of the calibration line and can increase by a factor of 2 when moving from around $\mathrm{pH} 7$ to around $\mathrm{pH} 2$ or 11 . Therefore, it is necessary to estimate the uncertainty separately for each measurement. For routine $\mathrm{pH}$ measurement, the uncertainty cannot be significantly reduced by using more accurate standard solutions than $\pm 0.02 \mathrm{pH}$ units; the uncertainty improvement is small. However, in routine $\mathrm{pH}$ determination this fundamental uncertainty (which in the case of the NBS scale amount to $\Delta \mathrm{pH}= \pm 0.005$ ) will be negligible (Leito et al., 2002). The total uncertainty in calculated values of $\mathrm{SI}_{\mathrm{c}}$ and $\mathrm{SI}_{\mathrm{d}}$ is about \pm 0.15 units, uncertainty for $\mathrm{SI}_{\mathrm{c}}$ and $\mathrm{SI}_{\mathrm{d}}$ are a measure of range of measurements from the average, also called deviation or error (Vern Lindberg, 2000).

\section{Results And Discussion}

\section{Water Quality: Parameters and Discharge}

Statistical calculations were conducted using the statistical software packages SPSS version 15 for windows XP. Tables 1, 2, 3, and 4 showed the descriptive statistics (minimum, maximum, average, standard deviation, and coefficient of variation $(\mathrm{Cv})$ ) of the samples collected from the different springs and wells in the studied area.

Figures 5 and 6 showed the seasons of Al-Dhaher cave spring and the type of springs, respectively with the concentration values of $\mathrm{pH}$, TDS, EC, T, Q, $\mathrm{Cl}^{-}, \mathrm{SO}_{4}{ }^{2-}, \mathrm{NO}_{3}{ }^{-}, \mathrm{HCO}_{3}{ }^{-}, \mathrm{K}^{+}, \mathrm{Na}^{+}, \mathrm{Mg}^{2+}$ and $\mathrm{Ca}^{2+}$.

In Tables $1,2,3,4,5$ and 6 the essential values of statistical measures of $\mathrm{pH}, \mathrm{Cl}^{-}, \mathrm{HCO}_{3}^{-}, \mathrm{SO}_{4}{ }^{2-}$ and $\mathrm{NO}_{3}$ parameters are also given and discussion.

Many water quality parameters showed striking seasonal variations. Temperature and seasonal variation is relatively uniform during the time. There is also a variation in concentrations and discharge. There are different reasons for these variations. Some of them depend on discharge and seasonality; the magnitudes of the fluctuations in discharge are much greater than those of concentrations. The ratio of highest and lowest concentrations of cations and inions for water discharge is large $(58.75: 1)$ followed by $\mathrm{K}^{+}(33.5: 1)$ and $\mathrm{Na}^{+}$ (19.1:1). There is low ratio for $\mathrm{Cl}^{-}(2: 1)$, sulphate, $\mathrm{SO}_{4}{ }^{2-}(1.84: 1), \mathrm{NO}_{3}{ }^{-}(1.54: 1), \mathrm{Mg}^{2+}(1.39: 1), \mathrm{Ca}^{2+}(1.34: 1)$, $\mathrm{HCO}_{3}{ }^{-}(1.33: 1)$, EC (1.21:1), TDS (1.21:1) and temperature, $\mathrm{T}(1.17: 1)$. The dominant anion and cation in the water of Al-Dhaher springs is $\mathrm{HCO}_{3}{ }^{-}$and $\mathrm{Ca}^{2+}$, respectively. The values of $\mathrm{NO}_{3}{ }^{-}$show may be anthropogenic influence but it is five times less than those in the Jordanian wells in which the medium level of $\mathrm{NO}_{3}{ }^{-}$is $33 \mathrm{mg} / \mathrm{l}$ (Obeidat et al., 2008).

Figure 7 shows the relation between temperature $(\mathrm{T})$ and discharge $(\mathrm{Q})$, while Figure 10 shows relation of water quality parameters and discharge at Al-Dhaher springs. The relations show that the data of the discharge $(\mathrm{Q})$ with variables of $\mathrm{T}, \mathrm{Ca} 2+, \mathrm{Mg}^{2+},\left(\mathrm{Ca}^{2+}+\mathrm{Mg}^{2+}\right)$, and $\mathrm{HCO}_{3}{ }^{-}$strong relation from a strong distribution not only in skewness, but also by the number of the other values that may be far from the normality values. It is noted that only temperature is approaching around normal values. As presented in Figure 10, some outliers and extreme values for the variables of $\mathrm{Ca}^{2+}, \mathrm{Mg}^{2+}$, and $\mathrm{HCO}_{3}^{-}$are recorded. The extreme values for these variables are due to carbonate aquifers, while the extreme values of other variables are unexpected and may be due to non-suitable measurements or due to the contamination of water samples from human disposals.

\section{Seasonal Variation in the Water Quality}

The importance of karst caves in the study area is to determine the types of rocks and their effect to dissolve in aqueous solutions, to study the most important geological structures that appear in the region and its relationship with the phenomenon of karstification (Dar et al., 2011), to study the characteristics of thermodynamics of groundwater and their impact on the karstification, and to study the effect of rainfall and runoff, and how effective they are in the formation of stalactite and stalagmites.

The amount of rainfall in the study area is limited to winter and is the only source of ground water recharge; seasonal variation could be noticed in the water quality of the different springs and wells. 
Three types of variations were noticed during this study between the water quality of the samples collected in winter and those collected in summer. Winter samples are slightly diluted than those collected in summer (Figs. 5 and 6) and have slightly lower concentrations of cations: $\mathrm{Ca}^{2+}, \mathrm{Mg}^{2+}, \mathrm{Na}^{+}, \mathrm{K}^{+}$and anions: $\mathrm{HCO}_{3}^{-}, \mathrm{Cl}^{-}, \mathrm{NO}_{3}^{-}$, $\mathrm{SO}_{4}{ }^{2-}$. This is may be due to the rainfall, infiltration and ground water recharge during winter. While during samples analyses taken along channel of stream from upstream to downstream increase was found in the $\mathrm{Na}^{+}$ and $\mathrm{Cl}^{-}$caused by evaporation and thus decreasing the discharge of water gradually until it dries up completely. The plot figures (Figs. 7, 8, 9, 10,11) and the results of the distribution for normality showed almost a normal distribution at all seasons for all parameters analyses. Samples were collected in two different seasons, summer and winter; therefore, it was very important to check whether there are significant differences in the mean concentrations of the different parameters between the two seasons.

Mann-Whitney test showed no significant differences between the mean concentrations of all of the studied parameters except the temperature and ions of $\mathrm{Na}^{+}$and $\mathrm{K}^{+}$. Based on this result, the available data of all springs and wells will be averaged regardless the season for further statistical analysis.

Physical and chemical analyses (Tables 1, 2, 3, and 4) for all types of water samples (Al-Dhaher Cave Spring, Ain Zubia, Ain Zgaeg, and wells), as well as the calculated indexes of saturation of calcite $\left(\mathrm{SI}_{\mathrm{c}}\right)$ and of dolomite $\left(\mathrm{SI}_{\mathrm{d}}\right)$ and some of the calculated ion ratios. Tables 1, 2, 3, and 4 also show the average calculated values of the different chemical parameters, their minimum, maximum, average, standard deviation $(\sigma x)$ and the value of the coefficient of variation $\left(\mathrm{C}_{\mathrm{v}} \%\right)$, where the coefficient of variation $\left(\mathrm{C}_{\mathrm{v}}\right)=(\sigma \mathrm{x} / \text { average })^{*} 100$. While, the same procedures and equations were used to calculate the data and get the results, at many different studies and interpretations in many researches, as Garrels and Christ, 1965; Langmuir 1971; Thrailkill, 1976; Drever 1983; Dreybrodt and Gabrovšek, 2003.

These results confirm the data on the nature of Al-Dhaher Cave Spring karst structure and the groundwater flow regime obtained by other methods of exploration (e.g. Abu-Jaber et al. 2006; Obeidat et al. 2008). It was found that inflow of the input water types of rainwater enhance the dissolutional process of the aquifer system.

\section{pH and Temperature of Ground Water}

$\mathrm{pH}$ and Temperature of water samples were determined in the field. Small changes in $\mathrm{pH}(0.3$ units or even less) are usually associated with relatively large changes in other water qualities. Most natural waters will have $\mathrm{pH}$ values from $\mathrm{pH} 5.0$ to $\mathrm{pH}$ 8.5. The acidic, freshly fallen rainwater may have a $\mathrm{pH}$ value about 5.5 to 6.0. If it reacts with soils and minerals containing weak alkaline materials, the hydrogen ion concentration will decrease. The water may become slightly alkaline with a $\mathrm{pH}$ of 8.0-8.5. Sudden changes in $\mathrm{pH}$ values serve as warning signals that water quality may be adversely affected through the introduction of contaminates.

Correlation coefficient and regression analysis for figures (Fig. 7) of curve fitting. These procedures are used for looking at the relationship between different factors, and for graphing the results in statistically meaningful ways.

There is a three stages procedure:

1. Plot the results on graph paper, as a result of SPSS program, and does the relationship look (or is expected to be) linear, or is it logarithmic, or sigmoid ( $\mathrm{S}$-shaped).

2. Calculate the correlation coefficient, and how close the fit is, in statistical terms .

3. If the correlation coefficient is significant, and other conditions are met, proceed to regression analysis, which gives the equation for the line of best fit.

The $\mathrm{pH}$ values of all types of groundwater are relatively stable (pH: 7.19) with a standard deviation of 0.22 (Table 5), while $\mathrm{pH}$ values are: 7.05-7.44 in the Al-Dhaher Cave Spring, 6.78-7.14 in the Ain Zubia, 6.777.7 in the Ain Zgaeg, and 7.14-7.9 in the wells, with standard deviations of $0.166,0.101,0.26$, and 0.233 respectively (Tables $1,2,3,4)$.

Several factors affect the value of $\mathrm{pH}$ : source of the water, rainfall, water temperature, geology, soil and discharge. Due to a moderately affected all that are factors in the water of $\mathrm{Al}-\mathrm{Dhaher}$ Cave Spring, the value of $\mathrm{pH}$ for all water samples were arranged around normal $\mathrm{pH}$ (7). Generally, $\mathrm{pH}$ value was decreased through the recharge is higher during the low temperature season (winter), while it is increased through the recharge is lower during the higher temperature season (summer).

Temperature value varied from 14.3 to $16.68^{\circ} \mathrm{C}$ with average of $15.25^{\circ} \mathrm{C}$ (Table 5) reflecting the wide range of the temperature of the infiltrating recharge water (Tables 1, 2, 3, 4, 5). We note a strong correlation between temperature of the springs and discharge $r=0.97$ (Al-Dhaher Cave Spring), 0.83 (Ain Zubia), 0.80 (Ain Zgaeg), and 0.81 (wells) (Fig. 7), which express the relation of the recharge to the climate seasons.

\section{Total Dissolved Solids (TDS)}

Total dissolved solids (TDS) comprise inorganic salts, such as calcium, magnesium, potassium, sodium, bicarbonates, chlorides and sulfates, and some small amounts of organic matter that are dissolved in 
water. The TDS concentration is a secondary drinking-water standard and is regulated because of its esthetic effect rather than a health hazard. Elevated TDS indicate that the dissolved ions may cause the water to be corrosive, of salty or brackish taste, resulting in scale formation.

As presented in Tables 1,2,3, and 4 all the collected water samples of springs and wells are fresh water type according to Carroll (1962) classification, with TDS values of 438-515 mg/l in the Al-Dhaher Cave Spring, 455-689 mg/l in the Ain Zubia, 408-692 mg/l in the Ain Zgaeg, and 428-586 mg/l in the wells water. Furthermore, higher values were recorded only in summer seasons in all water types.

The reason for this result is due to the decrease of surface rainwater into recharge of groundwater in the area, as well as in the case of groundwater depletion through irregular withdrawals of wells in the area and use in drinking.

Whenever, during the shortage supply season of surface water to the groundwater and withdrawn high amount of water to domestic homes, the final result are falling level of groundwater, and this works on the increase of the concentration ratio of the mass of dissolved solids in the water, which works to reduce water quality and increasing salinity as a final result, and transition from suitable drinking fresh water to not suitable salt water.

\section{Electrical Conductivity (EC)}

The electrical conductivity (EC) of water is a measure of the total salt content of water based on the flow of electrical current through the sample. The higher the salt content the greater the flow of electrical current.

The electrical conductivity of the water depends on the water temperature: the higher the temperature, the higher the electrical conductivity would be. The electrical conductivity of water increases by $2-3 \%$ for an increase of 1 degree Celsius of water temperature (Smart, Growing Intelligently, 2012).

Since the electrical conductivity is a measure to the capacity of water to conduct electrical current, it is directly related to the concentration of salts dissolved in water, and therefore to the Total Dissolved Solids (TDS). Salts dissolve into positively charged ions and negatively charged ions, which conduct electricity. Since it is difficult to measure TDS in the field, the electrical conductivity of the water is used as a measure. EC for drinking water can be converted to TDS using the following calculation (http://www.lenntech.com/applications/ultrapure/conductivity/water-conductivity. htm\#ixzz2E4EaXuDf, 2012): $\mathrm{TDS}(\mathrm{mg} / \mathrm{l})$ or $(\mathrm{ppm})=0.5 \mathrm{X} \mathrm{EC}(\mathrm{dS} / \mathrm{m}$ or $\mathrm{mmho} / \mathrm{cm})$ or $=0.5 * 1000 \times \mathrm{EC}(\mu \mathrm{S} / \mathrm{cm})$

The electrical conductivity (EC) for all water samples varied from: 685 to $1162 \mu \mathrm{s} / \mathrm{cm}$ reflecting the different amounts of the total dissolved ions in water.

The measurements conducted during this study showed that the EC values ranged between 736-865 $\mu \mathrm{S} / \mathrm{cm}$ in the Al-Dhaher Cave Spring (Table 1), 764-1157 $\mu \mathrm{S} / \mathrm{cm}$ in the Ain Zubia (Table 2), 685-1162 $\mu \mathrm{S} / \mathrm{cm}$ in the Ain Zgaeg (Table 3), while in the wells the values ranged between 719-984 $\mu \mathrm{S} / \mathrm{cm}$ (Table 4). The highest values of $\mathrm{EC}$ in the springs and wells were recorded in summer seasons.

Tables 2, 3 and 4 show that the values of electrical conductivity (EC) for springs samples is low, and lie within the concentration level of standard drinking water. The EC values have less than value of seawater about fifty times (Suttar, 1990), and attributed this to the low of the Total Dissolved Solid in the spring's water in the study region, making it safe to drink. Except for some dissolved of $\mathrm{Ca}^{2+}, \mathrm{Mg}^{2+}$ and $\mathrm{HCO}_{3}^{-}$ions and granted by the relatively high value of the electrical conductivity, and due to the fact that water springs in the study area and in particular Al-Dhaher spring pass through the limestone and considered its aquifer.

Since the EC and TDS are measurements of the total salt content, they must be directly proportional. The correlation between these two parameters for the analyzed samples in this study was plotted in Figure 8 which showed a very strong linear correlation $(r=1)$ with a mathematical approximation of (TDS $\mathrm{mg} / \mathrm{l}=0.55$ $\mathrm{EC} \mu \mathrm{S} / \mathrm{cm})$.

\section{Chemical Relations of Major Dissolved Ions}

Rainwater, as it passes through the air, through, and over the land, dissolves many chemical species. A wide range of different elements (e.g.: nitrogen, oxygen and carbon dioxide) can become dissolved in groundwater as a result of interactions with the atmosphere (Earle and Krogh, 2004; DHV, BV et al., 2002; Dreybrodt and Gabrovšek, 2003; Kempe et al., 2009), the surficial environment, soil and bedrock. The fact that it dissolves carbon dioxide from the air is important because when carbon dioxide is present in water, it forms carbonic acid and this acid enhances water's ability to dissolve chemical species (salts) contained in rocks and soil. In passing through polluted atmosphere, it is also possible for the water to dissolve gases associated with pollution such as sulphur and nitrogen oxides. Some of these gases can also make the water acidic, further adding to the water's ability to dissolve salts (DHV, BV et al., 2002).

By the time, that rainwater has passed over and through land to become groundwater or surface water, it has normally acquired many dissolved chemical species. Groundwater's tend to have much higher 
concentrations of most constituents than do surface waters, and deep groundwater's that have been in contact with rock for a long time tend to have higher concentrations than shallow and or young waters (Earle and Krogh, 2004). Clearly, the precise chemical composition of the water will depend upon the types of rock and soils with which the water has been in contact and this can be used to characterize a particular water by determining its chemical makeup. Tables 1, 2, 3 and 4 show the concentration of major ions in water of different springs at the different seasons in the study area, while Table 5 shows the mean of the major ion concentration in the same springs.

All analyzed samples are classified as calcium bicarbonate water. Ionic equivalent abundances show that cations $\mathrm{Ca}^{2+}>\mathrm{Mg}^{2+}>\left(\mathrm{Na}^{+}+\mathrm{K}^{+}\right)$and for anions $\mathrm{HCO}_{3}^{-}>\mathrm{Cl}^{-}>\mathrm{NO}_{3}^{-}>\mathrm{SO}_{4}{ }^{2-}$ dominate. Calcium and bicarbonate account for approximately $80 \%$ of the total ions. $\mathrm{NO}_{3}{ }^{-}$and $\mathrm{SO}_{4}{ }^{2-}$ account for only about 6 to $9 \%$ of the total ions in any given analyses. Most abundant ions $\mathrm{HCO}_{3}^{-}$and $\mathrm{Ca}^{2+}$ have also greater standard deviation (39 and 11.2, respectively), which indicates larger range of their values, while $\mathrm{Mg}^{2+}$ cations have also smaller standard deviation of 3.7, which indicates smaller range of their values (Table 5).

Correlations of concentrations between $\mathrm{Ca}^{2+}$ and $\mathrm{Mg}^{2+}$ with $\mathrm{HCO}_{3}^{-}$were very strong but that of $\mathrm{Ca}^{2+}(\mathrm{r}=0.98$ Al-Dhaher Cave Spring, 0.90 Ain Zubia, 0.90 Ain Zgaeg, and 0.94 wells water) were stronger than that of $\mathrm{Mg}^{2+}$ $(\mathrm{r}=0.96$ Al-Dhaher Cave Spring, 0.82 Ain Zubia, 0.87 Ain Zgaeg, and 0.70 wells water) (Fig. 9). Certainly, the main reason is the strength of the correlation and the chemical relation between $\mathrm{Ca}^{2+}$ with $\mathrm{HCO}_{3}^{-}$, which is stronger than the correlation strength between $\mathrm{Mg}^{2+}$ with $\mathrm{HCO}_{3}^{-}$.

A plot of equivalent concentrations of $\mathrm{Ca}^{2+}$ to $\mathrm{HCO}_{3}{ }^{-}$shows that $\mathrm{Ca}^{2+}$ balances $\mathrm{HCO}_{3}{ }^{-}$on a nearly onefor-one equivalent basis, and the $\mathrm{Y}$-intercept is near zero. Correlation between the sum of equivalents $\left(\mathrm{rCa}^{2+}+\right.$ $\left.\mathrm{rMg}^{2+}\right)$ and $\mathrm{HCO}_{3}{ }^{-}$is even very strong $(\mathrm{r}=0.98 \mathrm{Al}$-Dhaher Cave Spring, 0.92 Ain Zubia, 0.92 Ain Zgaeg, and 0.93 wells water) (Figure 9). Moderate to low correlations have been found between some of other ions like $\mathrm{Cl}^{-}$, $\mathrm{NO}_{3}{ }^{-}, \mathrm{SO}_{4}{ }^{2-}$ and $\mathrm{HCO}_{3}^{-}$, while that with $\mathrm{Ca}^{2+}$ and $\mathrm{Mg}^{2+}$ was very small and usually $\mathrm{r}<0.1$.

The concentration value of $\mathrm{Ca}^{2+}$ normal was below $15 \mathrm{mg} / \mathrm{l}$, although this can be above $100 \mathrm{mg} / \mathrm{L}$ where water is associated with aquifer of carbonate-rich rocks. $\mathrm{Mg}^{2+}$ concentrations were between 1 to $50 \mathrm{mg} / \mathrm{L}$ depending upon the rock type within the aquifer (DHV, BV et al., 2002).

Calcium and magnesium, when combined with bicarbonate, carbonate, sulphate (Kempe et al., 2009) and other species, contribute to the hardness of natural waters resulted on deposited scale when such waters are heated.

The concentration of carbonates and bicarbonates in water has a major effect on both the hardness and the alkalinity of water. The relative amounts of carbonate, bicarbonate and carbonic acid in water is related to the $\mathrm{pH}$. Under normal surface water $\mathrm{pH}$ conditions (i.e., less than $\mathrm{pH}=9$ ), bicarbonate predominates. Bicarbonate concentrations in natural waters range from less than $25 \mathrm{mg} / \mathrm{L}$ in areas of non-carbonate rocks to over $400 \mathrm{mg} / \mathrm{L}$ where carbonate rocks are present (DHV, BV et al., 2002).

In waters springs where the bicarbonate content is high, there is a tendency for calcium and magnesium to precipitate out as carbonates. As water is originated in marl, marly limestone, and limestone rocks, the total hardness is moderate to high, and the average value is nearly $355 \mathrm{mg} / \mathrm{L}$, also the $\mathrm{SO}_{4}{ }^{2-}$ concentration is low; the average value is $15.35 \mathrm{mg} / \mathrm{L}$ (Table 5).

Sulphate is present in all surface waters as it arises from rocks, which contains a high sulphate concentration. In addition to its role as a plant nutrient, high concentrations of sulphate can be problematic as they make the water corrosive to building materials and are capable of being reduced to hydrogen sulphide when zero dissolved oxygen conditions prevail in the water body (Kempe et al., 2009). Normally, sulphate concentrations in surface waters are between 2 and $80 \mathrm{mg} / \mathrm{L}$ although they may exceed $1000 \mathrm{mg} / \mathrm{L}$ if industrial discharges or sulphate-rich minerals are present (DHV, BV et al., 2002). The WHO (1993) guideline value for sulphate in drinking water is $400 \mathrm{mg} / \mathrm{L}$.

All natural waters contain sodium ions $(\mathrm{Na}+)$ as the element is one of the most abundant on the planet. High concentrations in ground waters, however, are normally associated with pollution from industrial discharges or sewage effluent or from dissolved of salt rocks, clays, or plagioclase intrusions. Normally, sodium concentrations in drinking water are below $200 \mathrm{mg} / \mathrm{L}$ depends on World Health Organization guideline limit.

Potassium ions are highly soluble and are essential for most forms of life. Potassium in the water environment is readily taken up by aquatic life, therefore (DHV, BV et al., 2002). The concentration of potassium ions (K+) in natural fresh waters is generally low (normally less than $10 \mathrm{mg} / \mathrm{L}$ ).

Chlorides in fresh waters generally come from rocks, the sewage, agricultural and industrial effluents. Fresh water concentrations of chloride are normally less than $40 \mathrm{mg} / \mathrm{L}$ and can be as low as $2 \mathrm{mg} / \mathrm{L}$ in waters, which have not been subject to pollution. Chloride concentrations over $100 \mathrm{mg} / \mathrm{L}$ give the water a salty taste and thereby make it unsuitable for drinking by humans or animals.

Though nitrate $\left(\mathrm{NO}_{3}{ }^{-}\right)$is listed as a major ion, moderately concentrations of nitrate average $20.34 \mathrm{mg} / \mathrm{L}$ (Table 5) have been reported from all springs in the study area where municipal wastewater from the countries over the aquifer has contaminated the groundwater. Excessive amount of nitrate in drinking water causes 
methaemoglobinaemia in bottle-fed infants (DHV, BV et al., 2002). WHO (1993) has recommended a guideline value of $10 \mathrm{mg} \mathrm{NO}_{3}{ }^{-} \mathrm{N} / \mathrm{L}$.

The moderately values for nitrate are observed for springs overlain by villages lacking a proper sewer system. There is a statistically significant correlation between nitrate concentration in spring water and the number of cesspools in the catchment area of each spring (Obeidat et al., 2008). This indicates that domestic wastewater form the major source of nitrate in the spring water. The time that the cesspools could take to contaminate the groundwater can vary depending on the depth to water table, degree of fracturing and karstification of the aquifer, and permeability of the aquifer (Gregory et al., 2001; Kiraly, 2003; Aloui and Chaabani, 2007).

Other potential sources of groundwater pollution include agricultural activities (fertilizers and animal husbandry, olive presses). The spatial variation in nitrate concentration can be attributed to different factors, such as hydrogeology, degree of karstification, and land use (Obeidat et al., 2008). $\mathrm{rCa}^{2+} / \mathrm{rMg}^{2+}$ ratio in groundwater has a clear geochemical implication; their values are usually lower in dolomite and higher in limestone or marl (Langmuir, 1971; Zotl, 1974; Eftimi and Benderev, 2007). The mean $\mathrm{rCa}^{2+} / \mathrm{rMg}^{2+}$ ratio for some springs in pure limestone of Albania is 11.8 and for some other dolomite springs is 2.1 (Eftimi, 2005) and for Iskrets spring is 3.3 (Eftimi and Benderev, 2007). The $\mathrm{rCa}^{2+} / \mathrm{rMg}^{2+}$ ratio for all springs in the study area is 1.92 (Table 5), while this ratio for all springs showed that the average values are: 1.54 in the Al-Dhaher Cave Spring, 2.49 in the Ain Zubia, 1.76 in the Ain Zgaeg, while in the wells the values average is 1.91, which suggest that water moves in limestone or that marly limestone is rich with dolomite.

Between $\mathrm{rCa}^{2+} / \mathrm{rMg}^{2+}$ ratios and the sums of $\mathrm{rCa}^{2+}+\mathrm{rMg}^{2+}$, an indirect correlation exists, that is related to the higher solubility of the limestone than that of dolomite (Eftimi and Benderev, 2007). As presented in Figure 9, correlation of sums of equivalent $\left(\mathrm{rCa}^{2+}+\mathrm{rMg}^{2+}\right)$ to $\left(\mathrm{rCa}^{2+} / \mathrm{rMg}^{2+}\right)$ ratio varies form very strong to very weak ( $\mathrm{r}=0.98$ Al-Dhaher Cave Spring, 0.74 Ain Zubia, 0.44 Ain Zgaeg, and 0.80 wells water).

These important data showing the aquifer source of spring water in the study area and the type of ground layers preserved of water, where the strength of the relationship between $\mathrm{Ca}^{2+}$ and $\mathrm{Mg}^{2+}$ ions absolutely demonstrates that source springs water coming out of the ground are carbonate rocks; limestone rich in $\mathrm{Ca}^{2+}$ and Dolomite rich in $\mathrm{Mg}^{2+}$.

\section{Water Chemistry and Discharge}

Based on water chemistry of springs there are two basic types possible that response to discharge according to Jacobson and Langmuir (1974). The first is the response controlled mainly by discharge and independent of the time of year. The second is the response controlled by the season and largely independent of the discharge. In the following, the quality variables of Al-Dhaher Cave Spring are controlled mostly by different seasons more than discharge.

Correlations of $\mathrm{Ca}^{2+}, \mathrm{Mg}^{2+},\left(\mathrm{Ca}^{2+}+\mathrm{Mg}^{2+}\right)$, and $\mathrm{HCO}_{3}{ }^{-}$to discharge (Q) of all springs and wells samples vary from very strong $(\mathrm{r}=0.95,0.96,0.96,0.90$ respectively) with Al-Dhaher Cave Spring (Fig. 10), to moderately strong $(r=0.69,0.71,0.70,0.87)$ with Ain Zubia, $(r=0.81,0.63,0.79,0.80)$ with Ain Zgaeg, and ( $r$ $=0.91,0.57,0.90,0.86)$ with wells water. While correlations were very low to no correlation of the other ions like $\mathrm{Cl}^{-}, \mathrm{NO}_{3}{ }^{-}$, and $\mathrm{SO}_{4}{ }^{2-}$ with discharge $(\mathrm{Q})$ and usually $\mathrm{r}<0.3$.

\section{Chemical Equilibrium and Saturation Indices}

The quality of the recharge water and its interactions with soil and rocks during its percolation and its storage in the aquifers are key factors in the chemistry of ground water. These interactions involve mainly dissolution and precipitation processes, which are controlled by the solubility products of the different involved mineral phases (Drogue, 1992). Generally, the saturation indices (SI) are used to express the tendency of water towards precipitation or dissolution. SI of the collected samples were calculated for the major mineral phases using the software package (PHREEQC for windows XP) according to Parkhurst and Appelo, (2001).

Calcite (limestone), marly limestone, and dolomite represent the major rocks that built-up the geology of the study area. According to tables 1,2,3, and 4 show that all the waters of the four clustering groups of springs and wells are supersaturated with respect to the main carbonate mineral (calcite and dolomite).

We noted also that the indexes of calcite $\left(\mathrm{SI}_{\mathrm{c}}\right)$ and dolomite $\left(\mathrm{SI}_{\mathrm{d}}\right)$ saturation with the sum of $\left(\mathrm{Ca}^{2+}+\right.$ $\left.\mathrm{Mg}^{2+}\right)$ of Al-Dhaher Cave Spring and other springs have very strong correlation $(\mathrm{r}=1.0,1.0$ to Al-Dhaher Cave Spring (Fig. 11), 0.95, 0.92 to Ain Zubia, 0.97, 0.96 to Ain Zgaeg, and 0.88, 0.92 to wells water). While the correlation coefficients of the $\mathrm{SI}_{c}$ and $\mathrm{SI}_{\mathrm{d}}$ to discharge $(\mathrm{Q})$ were very strong $(\mathrm{r}=0.97,0.96)$ to Al-Dhaher Cave Spring (Fig. 11), but for Ain Zubia, Ain Zgaeg, and wells water are also moderately strong $(\mathrm{r}=(0.68,0.67)$, $(0.77,0.68)$, and $(0.73,0.74)$, respectively). The saturation of the water with calcite and dolomite is higher during small discharges while it is smaller during large discharges of the springs, and this reflects the time duration of the contact of groundwater with the aquifer rocks (Eftimi and Benderev, 2007), and almost reflects the event season. 
Our data indicate that the springs are undersaturated with respect to calcite and dolomite, but the amount of undersaturation with respect to dolomite is much greater than that with respect to calcite. This is explained by the high solution kinetics of calcite in comparison with dolomite (Thrailkill, 1977; Appelo and Postma, 1999; Eftimi and Benderev, 2007).

\section{Physical Behaviors of the Karst Aquifers}

There are at least two end member types of the groundwater flow in karst aquifers: conduit flow and diffuse flow. The variation of the physical and chemical characteristics of the springs could be used to characterize physical behavior of the karst aquifers (Shuster and White, 1971; Jacobson and Langmuir, 1974; Kiraly, 2003; Aloui and Chaabani, 2007, Eftimi and Benderev, 2007), and this could be done having in sight also the limitations (Scanlon and Thrailkill, 1987). Changes in water chemistry may be described through the use of the coefficient of variation (Cv\%). According to Eftimi and Benderev (2007), the coefficients of variation result was greater for the conduit flow springs and less for diffuse flow springs.

Table 6 showed coefficients of variation for some variables measured in Al-Dhaher Cave Spring, Ain Zubia, Ain Zgaeg, and wells water compared with some literature data of Rock Spring, Thomson Spring (Jacobson and Langmuir, 1974), and Iskrets Spring (Eftimi and Benderev, 2007). Coefficients of variations of the used physical and chemical parameters suggest that such springs are of conduit type, while wells water suggests a diffuse flow water type. The mountain runoff provides essential groundwater recharge component. The tracer tests in the studied region, the monitoring on the spring flow-rate fluctuation and their connection to climatic factors prove water fast movement along karst channels during spring time and prove essential influence over saturated zone during dry seasons, as well (Benderev, 1989).

\section{Conclusions}

The results of geochemical study and water analyses clearly showed that the aquifer system is prone to karstification and clearly showed the impact of karst body on the chemical composition of the spring waters.

The significant variations of the Al-Dhaher Cave Spring flow rate were found to influence the alteration of main ions concentrations that characterize groundwater-rock interaction. The results also showed that the input water is aggressive to the rock component, but the output water is generally over saturated in respect to rock components. The flow rate variations also lead to a change of karstification activity indicators.

As a result there is a strong relationship prevailing between the quality and physical and chemical characteristics of spring's water in the study area, with the karstification processes that lead to the formation of limestone caves, and still those physical and chemical processes have an impact strong and accelerated the dissolved of carbonate rocks and composition caves karst. In addition, to helping water rainfall from the Earth's surface to the bottom, as well as the impact of rising and percolating groundwater act to top.

Further, it was found that Al-Dhaher Cave Spring is of conduit type as water moves mainly in large fractures, joints and solution openings. The spring is recharged by the infiltration of the precipitation in the AlDhaher Cave Spring karst basin and via sinkholes. Also, this study reveals that the main controlling factor of the chemistry of Al-Dhaher Cave Spring is the lithology of rocks, seasons and time to discharge of the spring.

\section{Acknowledgments}

The author highly appreciates the efforts and support of Associate Professor Dr. Kamal Al Shaib and Researcher Mr. Ameen Al-Zo'bi from Taibah University during all stages of this research.

\section{References}

[1]. Abu-Jaber, N., Mustafa, H., Melhem, D.M., 2006. Geology of the Dhaher (Bargish) Cave System, NW Jordan. Abhath Al-Yarmouk "Basic Sciences and Engineering", 15( 2), 351-363.

[2]. Aloui, T., Chaabani, F., 2007. Influence of fractures and karstification on the development of a quarry at Jebel Feriana, Tunisia. Springer-Verlag, Bull Eng. Geol. Environ., 66:345-351

[3]. Appelo, C., Postma, D., 1999. Geochemistry, Groundwater and Pollution. Leiden A. A. Balkema, 536 p.

[4]. Bender, F., 1974. Geology of Jordan. Supplementary Edition in English Gebrüder Borntraeger. Berlin, 187 p.

[5]. Benderev, A., 1989. Karst and Karst Waters of Ponor Mountain [Ph.D. thesis]: Bulgarian, Scientific Institute for Mineral Researches, $157 \mathrm{p}$.

[6]. Bogli, A., 1964. Mischungskorrosionein Beitrag zum Verkarstungsproblem: Erdkunde, v. 18, p. 83-92.

[7]. Bosák, P., 2003. Karst processes from the beginning to the end: How can they be dated? Speleogenesis and Evolution of Karst Aquifers. The Virtual Scientific Journal, 1(3), p.24.

[8]. Cañaveras, J.C., Cañaveras, S., Sanchez-Moral, V., Soler, V., Saiz-Jimenez. C., 2001. Microorganisms and microbially induced fabrics in cave walls. Geomicrobiological Journal, v. 18, 223-240.

[9]. Cañaveras, J.C., Hoyos, M., Sanchez-Moral, S., Sanz-Rubio, E., Bedoya, J., Solar, V., Groth, I., Schumann, P., Laiz, L., Gonzales, I., Saiz-Jimenez, C., 1999. Microbial communities associated with hydromagnesite and needle-fiber aragonite deposits in a karstic cave (Altamira, Northern Spain). Geomicrobiological Journal, v. 16, 9-25.

[10]. Carroll, D., 1962. Rain water as a chemical agent of geologic processes. A review. US Geological Survey, Water supply paper, 1535. V. G, 18 p. 
[11]. Dar, F.A., Perrin, J., Riotte, J., Gebauer, H.D., Narayana, , A.C., Ahmed, S., 2011. Karstification In The Cuddapah Sedimentary Basin, Southern India: Implications For Groundwater Resources. ACTA CARSOLOGICA 40/3, 457-472, POSTOJNA.

[12]. DHV, BV and DELFT HYDRAULICS with HALCROW, TAHAL, CES, ORG and JPS., 2002. Hydrology Project Training Module File: " 28 Major Ions in Water.doc" Version, 2002, New Delhi, CSMRS Building, 4th Floor, Olof Palme Marg, Hauz Khas, New Delhi - 110016 India, Tel: 6861681 / 84 Fax: (+ 91 11) 6861 685, E-Mail: dhvdelft@ del2.vsnl.net.in

[13]. Drever, I., 1983. The Geochemistry of Natural Waters. Prentice Hall, Harper and Row, 338 p.

[14]. Dreybrodt, W., 1981. Mixing corrosion on $\mathrm{CaCO}_{3}-\mathrm{CO}_{2}-\mathrm{H}_{2} \mathrm{O}$ systems and its role in the karstification of limestone areas. Chem. Geol., v. 32, 221-236.

[15]. Dreybrodt, W., Gabrovšek, F., 2003. Basic processes and mechanisms governing the evolution of karst. Speleogenesis and Evolution of Karst Aquifers. The Virtual Scientific Journal, 1(3), p.26.

[16]. Drogue, C., 1992. Hydrodynamics of Karst Aquifers: Experimental sites in The Mediterranean Karst, Southern France. In: Hydrogeology of Selected Karst Regions. William Back, Janet S. Herman, Henri Paloc, first edition. International Association of Hydrogeologists, Germany.

[17]. Earle, S., Krogh, E., 2004. Groundwater geochemistry of Gabriola, Shale, No. 7, 37-44.

[18]. Eftimi, R., 2005. Hydrochemical characteristics of some lithologically different karst massifs of Albania. In: Int. Conference and Field Seminars. Water Resources and Environmental Problems in Karst, Cvijić. Belgrade, p.499-504.

[19]. Eftimi, R., Benderev. A., 2007. Utilization of hydrochemical data for characterization of the karst system: example of Iskrets karst spring, Bulgaria: Review of the Bulgarian Geological Society. v. 68, part 1-3, p.167-174

[20]. El-Naser, H., 1991. Ground Water Resources of the Deep Aquifer System in NW Jordan - Hydrogeological and Hydrochemical quasi 3- dimensional Modeling [Ph.D. thesis]: Wurzburg, Germany.

[21]. Filipponi Marco, Jeannin Pierre-Yves, 2008. What makes a bedding plane favourable to karstification? The role of the primary rock permeability. Proceeding of 4th European Speleological Congress - Vercors 2008, p. 32-37.

[22]. Garrels, R., Christ, I., 1965. Solution, Minerals and Equilibria. New York, Harper and Row, 450 p.

[23]. Gregory A.S., Hugh H.M., Jason E.D., 2001. A simple map index of karstification and its relationship to sinkhole and cave distribution in Tennessee. Journal of Cave and Karst Studies 63(2): 67-75.

[24]. Groth, I., Schumann, P., Laiz, L., Sanchez-Moral, S., Cañaveras J.C., 2001. Geomicrobiological study of the Grotta dei Cervi, Porto Badisco, Italy. Geomicrobiological Journal, v. 18, p. 241-258.

[25]. Hill, C.A., 1987. Geology of Carlsbad Cavern and other caves in the Guadalupe Mountains, New Mexico and Texas. New Mexico Bureau of Mines and Mineral Resources, Bulletin, $150 \mathrm{p}$.

[26]. Hill, C.A., Forti, P., 1997. Cave Minerals of the World. 2nd edition, National Speleological Society, Huntsville, AL, 463 pp.

[27]. Howard, A.D., 1964. Processes of limestone cavern development. International Journal of Speleol., v.1, p.47-60.

[28]. Howard, A.D., 1966. Verification of the "Mischungskorrosion" effect. Cave Notes, v. 8, p. 9-12.

[29]. Jacobson, R., Langmuir, D., 1974. Controls on the quality variations of some carbonate spring water. Journal of Hydrology, v. 23, p. 247-265.

[30]. Jagnow, D.H., 1977. Geologic factors influencing speleogenesis in the Capitan Reef Complex, New Mexico and Texas [MS thesis]: University of New Mexico, Albuquerque: 203 p.

[31]. Jennings, J. N., 1985. Karst Geomorphology. Basil Blackwell, Oxford,136 p.

[32]. Kempe, S., Al-Malabeh, A., Al-Shreideh, A., Henschel, H.-V., 2006. Al-Daher Cave (Bergish), Jordan, the first extensive Jordanian limestone cave: A convective Carlsbad-type cave? Journal of Cave and Karst Studies 68(3), 107-114.

[33]. Kempe, S., Al-Malabeh, A., Henschel, H-V., 2009. Hypogene Karstification in Jordan (Bergish/Al-Daher Cave, Uwaiyed Cave, Beer Al-Malabeh Sinkhole), Hypogene Speleogenesis and Karst Hydrogeology of Artesian Basins. Ukrainain Institute of Speleology and Karstology, Special Paper 1, Simferopol, 280 pp. p. 253-256.

[34]. Kiraly, L., 2003. Karstification and Groundwater Flow. Speleogenesis and Evolution of Karst Aquifers. The Virtual Scientific Journal, 1(3), $26 \mathrm{p}$

[35]. Langmuir, D., 1971. The geochemistry of some carbonate ground waters of Central Pennsylvania: Geochem., Cosmochim. Acta, v. 35, p. 1023-1045.

[36]. Lauritzen, S.E., 2005. Karst as a weathering skin phenomenon: Is there a simple, scale-independent model for karstification: 14th International Congress of Speleology, Athen-Kalamos. v.63.p.1-6

[37]. Leito, Liisi Strauss, E. Koort, Viljar Pihl, 2002. Estimation of uncertainty in routine pH measurement. Accred. Qual. Assur., Springer-Verlag, v7, Issue 6, pp 242-249.

[38]. Maillet, E., 1905. Essai D'hdraulique Souterraine et Fluvial. Libraire Sci, A. Herman, Paris.

[39]. Masri, M., 1963. Report on the geology of the Amman-Zerqa area. Center of Water Authority, p. 1-74, Unpublished.

[40]. Mikbel, R., Abed, A., 1984. Discoveries of large phosphate deposits in northwest Jordan, Amman, Jordan (?).

[41]. Obeidat, M., Fayez Y.A., Nezar A.H., Adnan M.M., Faisal S.A., 2008. Assessment of nitrate contamination of karst springs, Bani Kanana, northern Jordan. Revista Mexicana de Ciencias Geológicas. v. 25, núm. 3, 2008, p. 426-437

[42]. Papadopoulou, M.P., Varouchakis, E.A., Karatzas, G.P., 2007. A Study of the Complex Karstification Phenomenon in Nature: An Analysis of The Flow In A Fractured Medium In Crete. Proceedings of the $10^{\text {th }}$ International Conference on Environmental Science and Technology Kos Island, Greece, 5-7 September 2007. p. 8.

[43]. Parkhurst D.L., Appelo, C.A.J., 2001. PHREEQC -A computer program for speciation, batch reactions, one dimensional transport and inverse geochemical calculations. US Geological Survey.

[44]. Polyak, V.J., Güven, N., 2000. Authigenesis of trioctahedral smectite in magnesium-rich carbonate speleothems in Carlsbad Cavern and other caves of the Guadalupe Mountains. New Mexico: Clays and Clay Minerals, v. 48, p. 317-321.

[45]. Polyak, V.J., McIntosh, W.C., Güven, N., Provencio, P., 1998. Age and origin of Carlsbad Cavern and related caves from 40Ar/39Ar of alunite. Science, v. 279, p. 1919-1922.

[46]. Rashed, K.A., 2012. Assessing Degree Of Karstification: A New Method Of Classifying Karst Aquifers, Sixteenth International Water Technology Conference, IWTC 16, 2012, Istanbul, Turkey, p. 9.

[47]. Runnells, D.D., 1969. Diagenesis, chemical sediments, and the mixing of natural waters. Journal of Sedimentology and Petrology, v. 39, p. $1188-1201$.

[48]. Sadiq, A.M., Nasir, S.J., 2002. Middle Pleistocene karst evolution in the State of Qatar, Arabian Gulf. Journal of Cave and Karst Studies 64(2): 132-139.

[49]. Smart, Growing Intelligently, 2012. Smart Web! Fertilizer Management Software - Global Activity. Open field applications: fertigation, hydroponics, Interpretation of soil, water and tissue analysis. Nutritional data of hundreds of crops. 15 Eshkol St., Hod Hasharon 45343. 
[50]. Sanchez-Moral S., Cañaveras J.C., Laiz L., Saiz-Jimenez C., Bedoya J., Luque, L., 2003. Biomediated precipitation of calcium carbonate metastable phases in hypogean environments. a short review: Geomicrobiological Journal, v. 20, p. 491-500.

[51]. Scanlon, B., Thrailkill, J., 1987. Chemical similarities among physically distinct springs type in a karst terrain. Journal of Hydrology, v. 89, p. 259-279.

[52]. Screaton, E., Martin, J. B., Ginn, B., Smith, L., 2004. Conduit Properties and Certification in the Unconfined Floridan Aquifer. GROUND WATER, 42(3), 338-346.

[53]. Shuster, E., White, W., 1971. Seasonal fluctuations in the chemistry of limestone springs: a possible mean for characterizing carbonate aquifers. Journal of Hydrology, v.14, p. 93-128.

[54]. Suttar S., 1990. Ribbons of Blue Handbook. Scitech, Victoria

[55]. Thrailkill, J., 1976. Carbonate equilibria in karst water. In: Karst Hydrology and Water Resources. Proceed of USYugoslavian Symp, Dubrovnik, p. 745-766.

[56]. Thrailkill, J., 1977. Relative solubility of limestone and dolomite. Karst Hydrology, AIH Memoirs, v.12, p. 491-500.

[57]. Vern Lindberg, 2000. Uncertainties and Error Propagation: Part I of a manual on Uncertainties, Graphing, and the Vernier Caliper.

[58]. World Health organization (WHO), 1993. Guidelines for drinking water quality-recommendations. Geneva, World Health Organization, 2nd edition.

[59]. Wolfart, R., 1959. The Hashemite Kingdom of Jordan, Geology and hydrology of the Irbid District. Bundesanstaft Für Bodenforschung, Hannover.

[60]. Zotl, J., 1974. Karst hydrogeology. Berlin, Springer-Verlag, 291 p.

Electronic References

http://www.lenntech.com/applications/ultrapure/conductivity/water-conductivity. htm\#ixzz2E4EaXuDf, 201

\section{Figures 1-11}

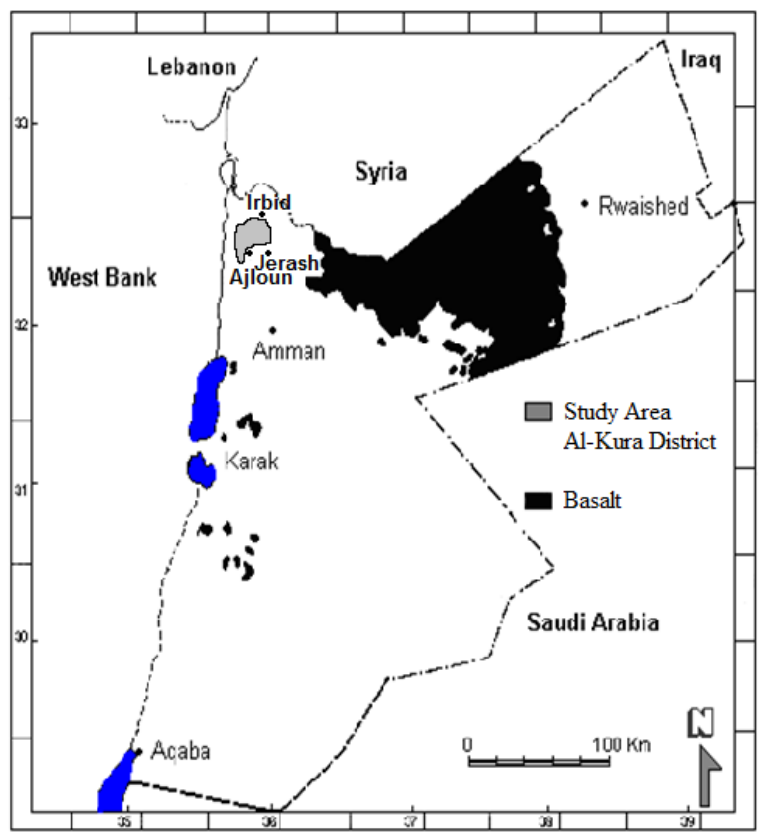

Figure (1.a). Location map of the study area in Jordan. 


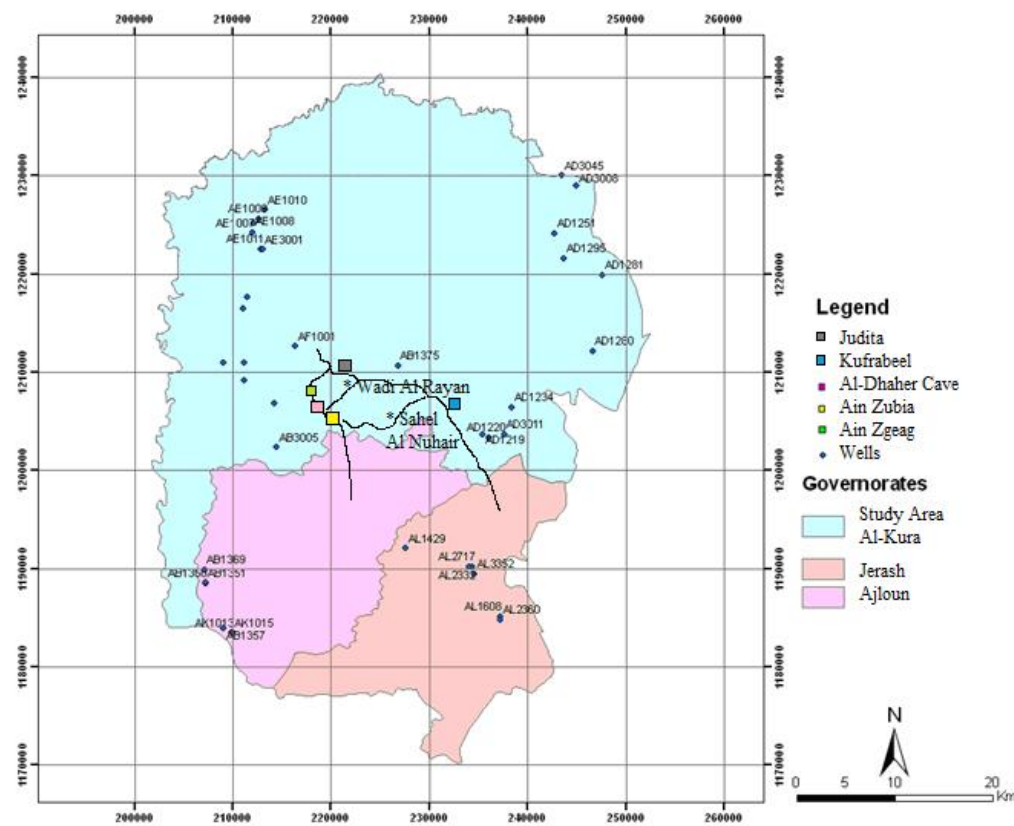

Figure (1.b). Location map of Irbid governorate, Al-Kura District, springs, and wells of the study area.

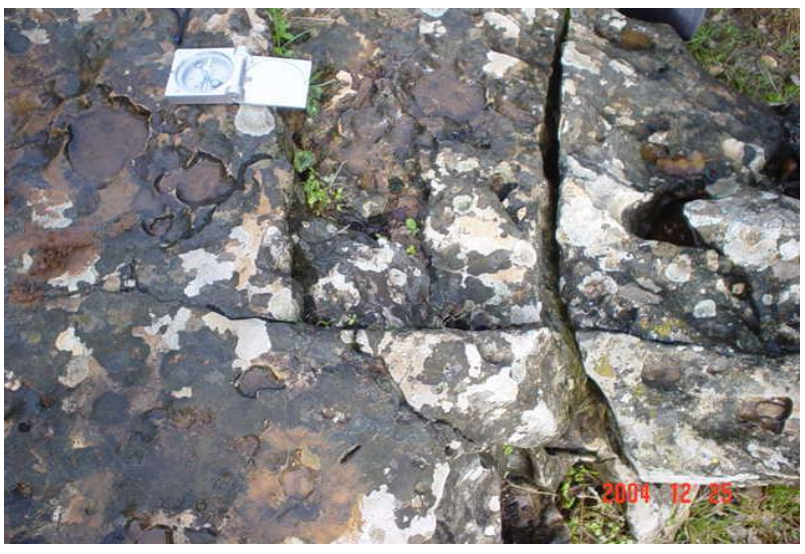

Figure 2. Limestone rock shows fractures and joints at the surface over the cave area.

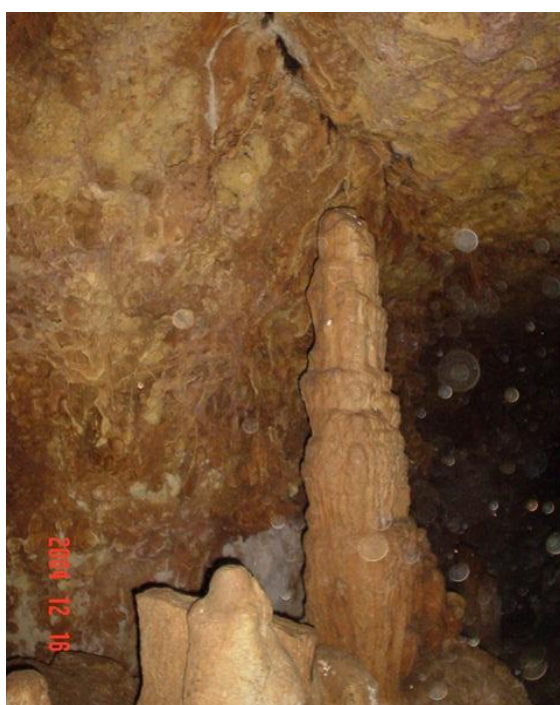

Figure 3. Stalagmite shape inside of Al-Dhaher Cave grow as a cylinder shape with length about two meters and about one meter diameter. 

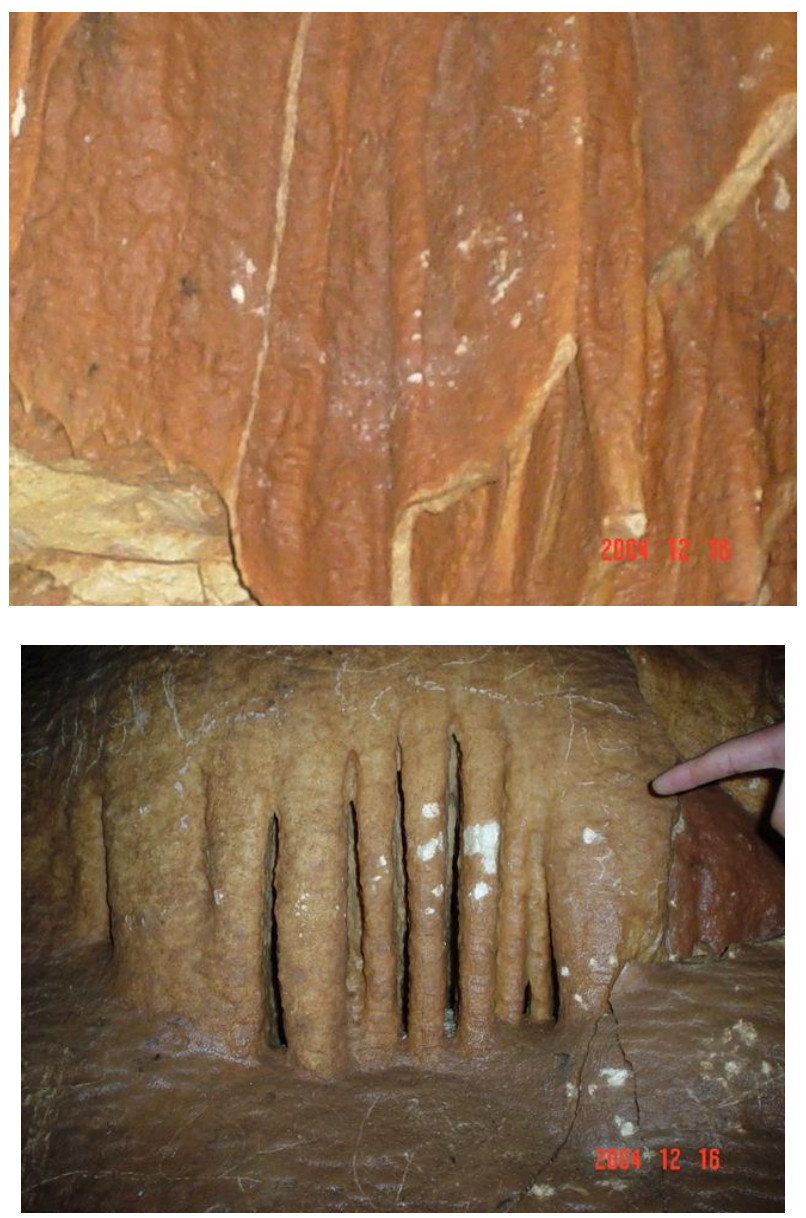

Figure 4. Curtain shape developed from carbonate water trickles down an inclined walls.

Al-Dhaher Cave Spring

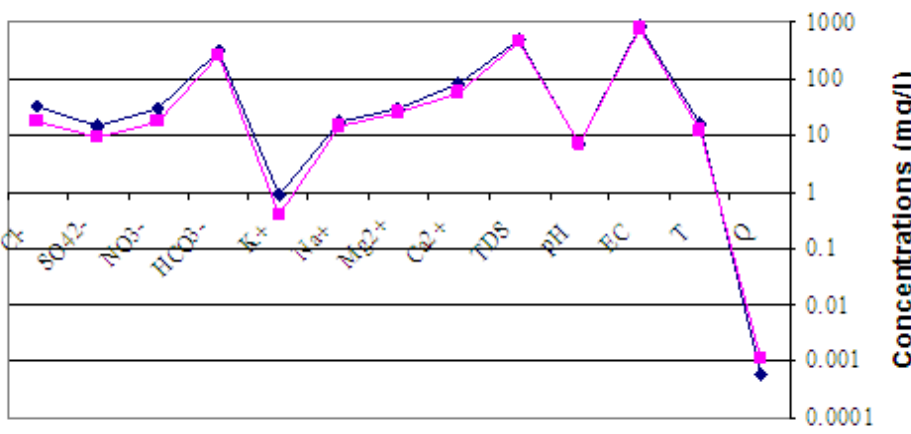

$\multimap$ ๑ Summer —-Winter

Figure 5. Plot of the samples collected in summer and winter from the Al-Dhaher Cave Spring. 


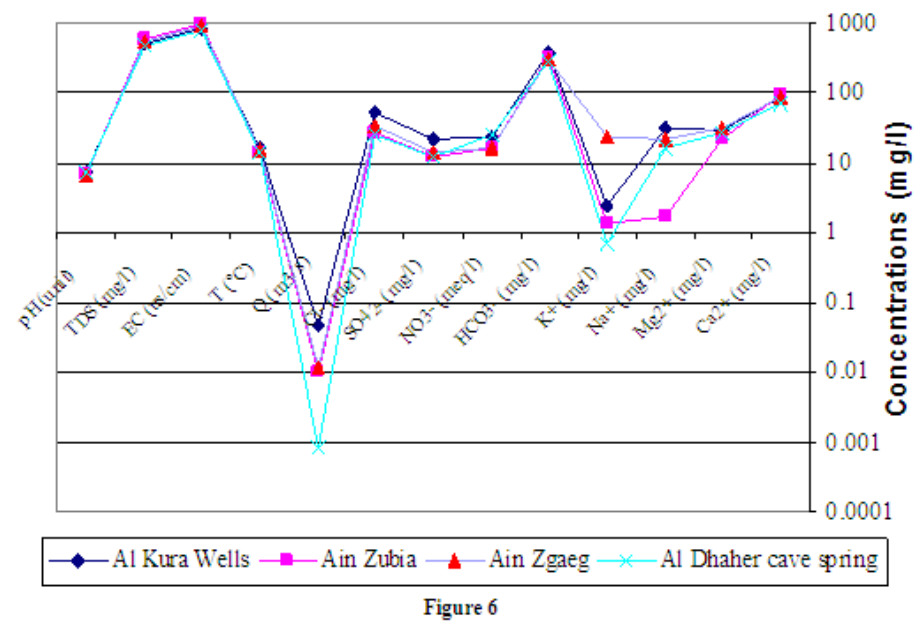

Figure 6. The comparison plot of the samples collected in summer and winter from the Al-Dhaher Cave Spring, Ain Zubia, Ain Zgaeg, and Al-Kura wells water.

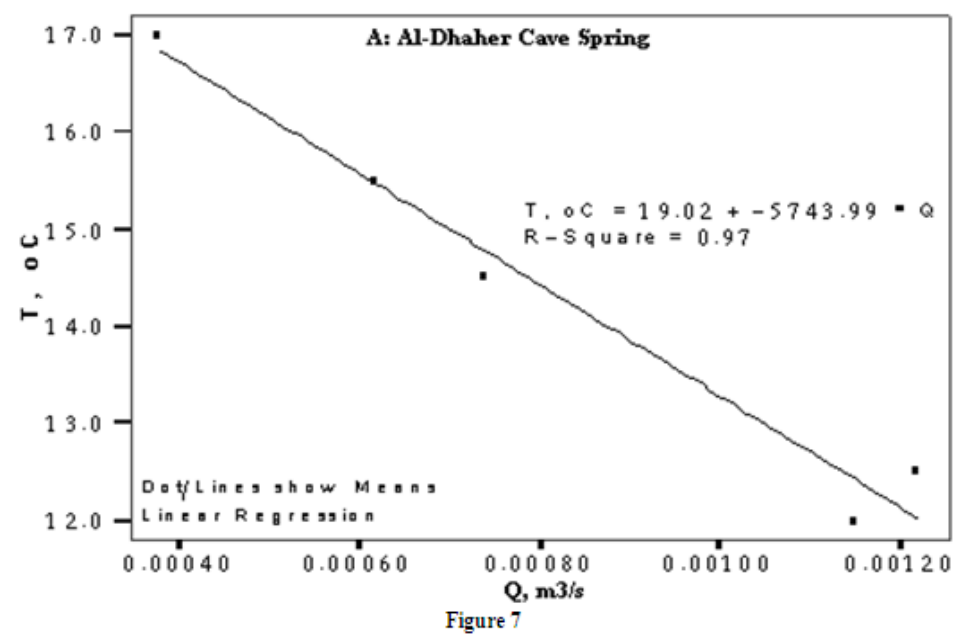

Figure 7. Relation between temperatures (T) of ground water with discharge (Q) to Al-Dhaher Cave Spring.

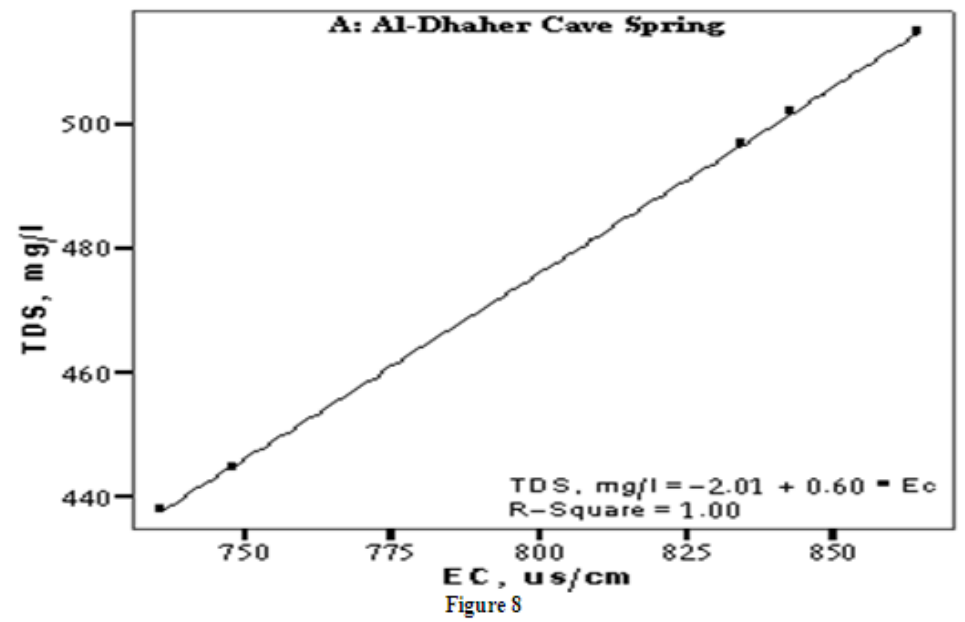

Figure 8. Relation between total dissolved solid (TDS) of ground water with electrical conductivity (EC) to AlDhaher Cave Spring. 

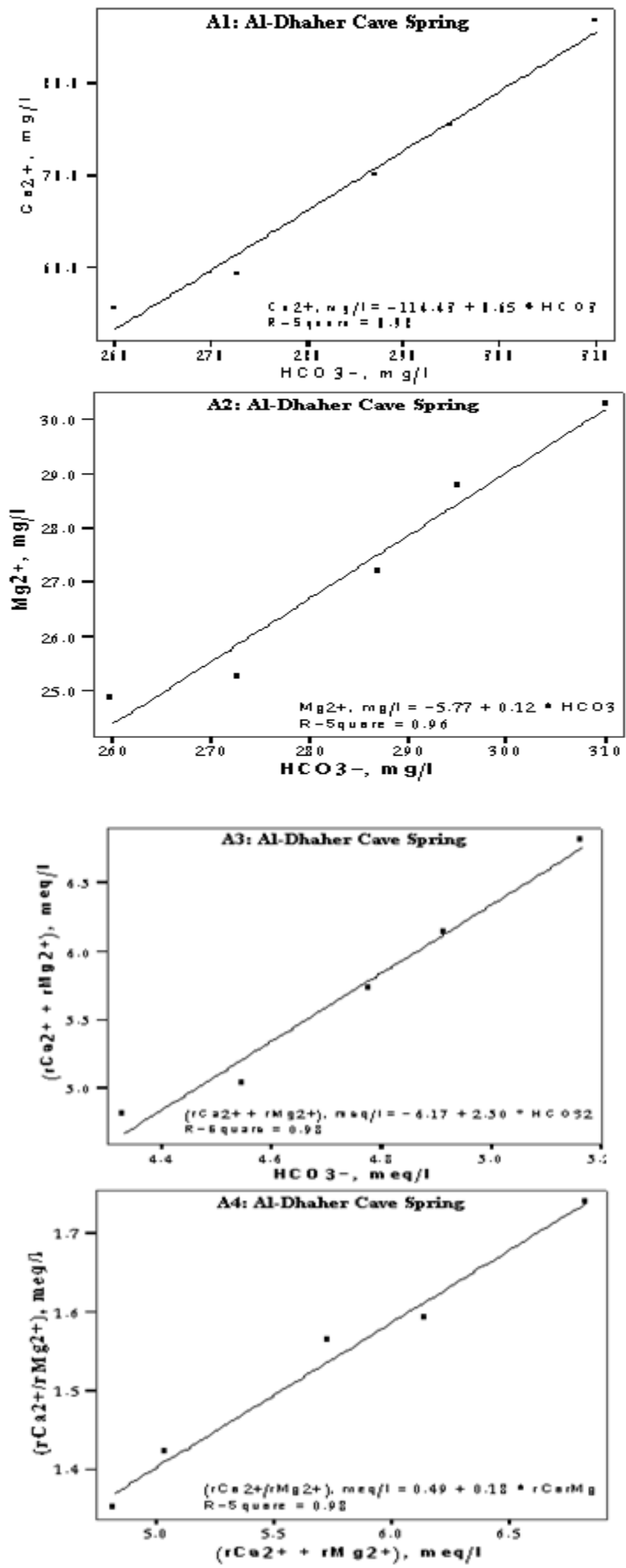

Figure 9

Figure 9. Relation between $\mathrm{HCO}_{3}{ }^{-}$and other major cations; (A1, A2, A3, A4) to Al-Dhaher Cave Spring. 

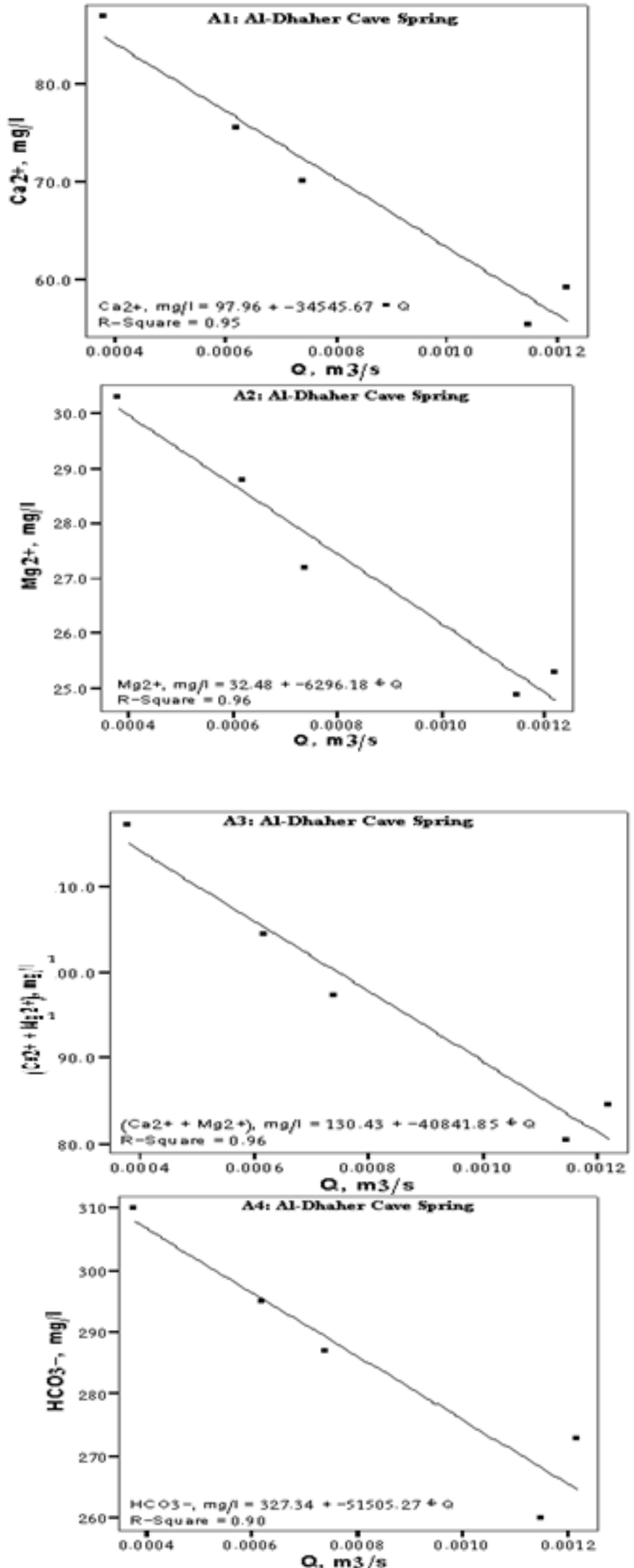

Figure 10

Figure 10. Relation between discharge $(\mathrm{Q})^{-}$and other major ions; (A1, A2, A3, A4) to Al-Dhaher Cave Spring. 

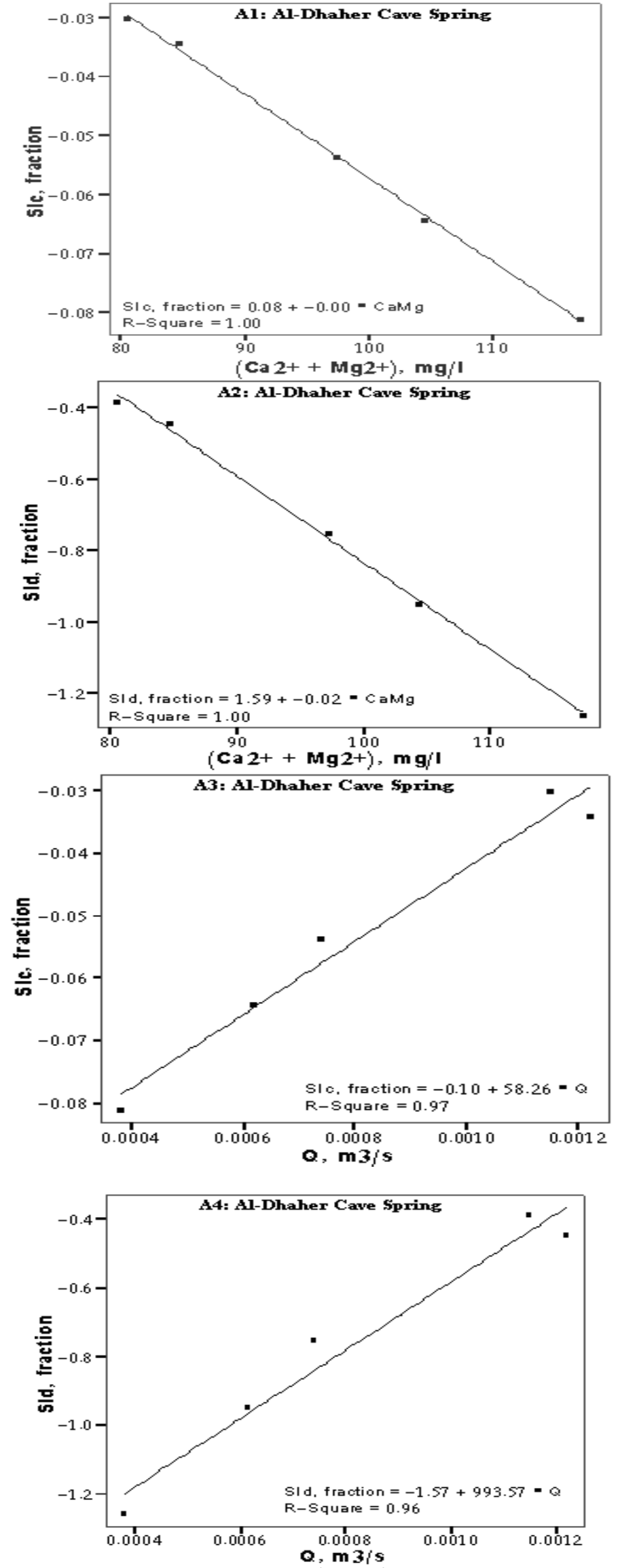

Figure 11. Relation between $\mathrm{SI}_{\mathrm{c}}$ and $\mathrm{SI}_{\mathrm{d}}$ versus of $\left(\mathrm{Ca}^{2+}+\mathrm{Mg}^{2+}\right)$ and discharge (Q), (A1, A2, A3, A4) to AlDhaher Cave Spring. 
Describe and Statistical Evaluation of Hydrochemical Data of Karst Phenomena in Jordan:

Table 1. Physical and chemical analyses and statistical parameters of the Al-Dhaher Cave Spring.

\begin{tabular}{|c|c|c|c|c|c|c|c|c|c|c|c|c|c|c|c|c|c|c|}
\hline Spring Name & $\begin{array}{c}Q \\
\mathrm{~m}^{\mathrm{i} / \mathrm{s}}\end{array}$ & $\begin{array}{l}\mathrm{T} \\
{ }^{\circ} \mathrm{C}\end{array}$ & $\begin{array}{c}\mathrm{EC} \\
\mathrm{w} s \mathrm{~cm}\end{array}$ & $\begin{array}{l}\mathrm{pH} \\
\text { unit }\end{array}$ & $\begin{array}{l}\mathrm{TDS} \\
\mathrm{mg} 1\end{array}$ & $\begin{array}{l}\mathrm{Ca} \mathrm{a}^{*-} \\
\mathrm{mg} 1\end{array}$ & $\begin{array}{l}\mathrm{Mg}:- \\
\mathrm{mg} /\end{array}$ & $\begin{array}{l}\mathrm{Na}^{*} \\
\mathrm{mg} / 1\end{array}$ & $\begin{array}{c}\mathrm{K}^{*} \\
\mathrm{mg} / 1\end{array}$ & $\begin{array}{l}\mathrm{Na}^{2}-\mathrm{K}^{*} \\
\mathrm{mg} 1\end{array}$ & $\begin{array}{c}\mathrm{rCa}^{*}+\mathrm{rMg}^{3} \\
\operatorname{meq} 1\end{array}$ & $\mathrm{rCa}+\mathrm{rMg}^{-}$ & $\mathrm{SI}_{\mathrm{f}}$ & $\mathrm{SI}_{s}$ & $\begin{array}{l}\mathrm{HCO} ; \\
\mathrm{mg} 1\end{array}$ & $\begin{array}{l}\mathrm{No}^{-} \\
\mathrm{mg} / 1\end{array}$ & $\begin{array}{l}\mathrm{SO}^{2} \\
\mathrm{mg} 1\end{array}$ & $\underset{\mathrm{mg} 1}{\mathrm{Cl}}$ \\
\hline \multirow{5}{*}{$\begin{array}{l}\text { Al Dhaher Cave } \\
\text { Spring }\end{array}$} & 0.00074 & 14.5 & 835 & 7.2 & 497 & 70.2 & 27.2 & 16.2 & 0.84 & 17.04 & 5.741 & 1.565 & -0.054 & -0.75 & 287 & 28.5 & 11.5 & 21.0 \\
\hline & 0.00115 & 12 & 748 & 7.05 & 445 & 55.6 & 24.9 & 15 & 0.45 & 15.45 & 4.823 & 1.354 & -0.03 & -0.385 & 260 & 16.7 & 8.8 & 15.1 \\
\hline & 0.00062 & 15.5 & 843 & 7.32 & 502 & 75.7 & 28.8 & 18.6 & 0.95 & $19.55^{\circ}$ & 6.147 & 1.594 & 0.064 & -0.949 & 295 & 30.1 & 14.1 & 35.0 \\
\hline & 0.0012 & 12.5 & 736 & 7.07 & 438 & 59.4 & 25.3 & 15.3 & 0.31 & 15.61 & 5.046 & 1.424 & -0.034 & -0.445 & 273 & 18.9 & 9.7 & 18.4 \\
\hline & 0.00038 & 17 & 865 & 7.44 & 515 & 86.9 & 30.3 & 19.2 & 0.98 & 20.18 & 6.829 & 1.739 & -0.081 & -1.258 & 310 & 32.3 & 16.5 & 38.4 \\
\hline Minimum & 0.00038 & 12 & 736 & 7.05 & 438 & 55.6 & 24.9 & 15 & 0.31 & 15.45 & 4.823 & 1.354 & -0.081 & -1.258 & 260 & 16.7 & 8.8 & 15.1 \\
\hline Naximum & 0.00122 & 17 & $865^{-}$ & 7.44 & 515 & 86.9 & 30.3 & 19.2 & 0.98 & 20.18 & 6.829 & 1.739 & -0.03 & -0.385 & 310 & 32.3 & 16.5 & 38.4 \\
\hline Average & 0.00082 & 14.3 & 805.4 & $7.216^{-1}$ & $479.4^{-}$ & 69.56 & 27.3 & $16.86^{-}$ & 0.71 & 17.6 & 5.717 & 1.535 & 0.053 & -0.758 & 285 & 25.3 & 12.12 & 25.58 \\
\hline $2 \mathrm{x}$ & 0.00036 & 2.08 & 39.06 & 0.166 & 35.3 & $12.62^{-}$ & 2.29 & 1.92 & 0.31 & 2.2 & 0.817 & 0.151 & $0.021^{-}$ & 0.362 & 19.35 & 7.021 & 3.177 & 10.43 \\
\hline $\mathrm{Cv}$ & 0.43392 & 0.145 & 0.073 & 0.023 & 0.074 & 0.181 & 0.084 & $0.114^{-}$ & 0.434 & $0.125^{-}$ & 0.143 & 0.099 & -0.4 & -0.477 & 0.068 & 0.278 & 0.262 & 0.408 \\
\hline $\mathrm{Cr} \%$ & 43.392 & 14.54 & 7.33 & 2.3 & 7.4 & 18.1 & 8.4 & 11.4 & 43.4 & 12.5 & 14.3 & 9.9 & -40 & -47.7 & 6.8 & 27.75 & 26.2 & 40.8 \\
\hline
\end{tabular}

$* \mathrm{raa}^{2+}(\mathrm{meq} / \mathrm{l})=\mathrm{meq} / \mathrm{l}$ of $\mathrm{Ca}^{2+}=\left(\mathrm{mg} / \mathrm{l}\right.$ of $\left.\mathrm{Ca}^{2+}\right) /$ equivalent weight of $\mathrm{Ca}^{2+}$

* equivalent weight of $\mathrm{Ca}^{2+}=$ atomic weight of $\mathrm{Ca}^{2+} /$ valence of $\mathrm{Ca}^{2+}=40.08 / 2=20.04$

* equivalent weight of $\mathrm{Mg}^{2+}=$ atomic weight of $\mathrm{Mg}^{2+} /$ valence of $\mathrm{Mg}^{2+}=24.305 / 2=12.1525$

* Saturation Index: $\mathrm{SI}_{\mathrm{c}}=\left(\mathrm{Ca}^{2+}\right)\left(\mathrm{CO}_{3}^{2-}\right) / \mathrm{K}_{\mathrm{c}}$

* Saturation Index: $\mathrm{SI}_{\mathrm{d}}=\left(\mathrm{Ca}^{2+}\right)\left(\mathrm{Mg}^{2+}\right)\left(\mathrm{CO}_{3}^{2-}\right) / \mathrm{K}_{\mathrm{d}}$

* Coefficient of variation $(\mathrm{Cv})=\sigma \mathrm{x} /$ average

$* \mathrm{Cv} \%=100 \sigma \mathrm{x} /$ average

Table 2. Physical and chemical analyses and statistical parameters of the Ain Zubia spring

\begin{tabular}{|c|c|c|c|c|c|c|c|c|c|c|c|c|c|c|c|c|c|c|}
\hline & $\begin{array}{l} \\
m^{3} / s\end{array}$ & $\begin{array}{l}\mathrm{T} \\
{ }^{\circ} \mathrm{C}\end{array}$ & $\begin{array}{l}E C \\
\mathrm{ws} \mathrm{cm}\end{array}$ & $\begin{array}{l}\mathrm{pH} \\
\text { unit }\end{array}$ & $\begin{array}{l}\mathrm{DSS} \\
\mathrm{mg} 1\end{array}$ & $\begin{array}{l}\mathrm{Cs}^{* *} \\
\mathrm{mg} 1\end{array}$ & $\begin{array}{l}\mathrm{Mg}{ }^{*} \\
\mathrm{mg} 1\end{array}$ & $\begin{array}{l}\mathrm{Ng}^{*} \\
\mathrm{mg} 1\end{array}$ & $\begin{array}{l}\mathrm{K} \\
\mathrm{mg} 1\end{array}$ & $\begin{array}{l}\mathrm{Nz}^{2}+\mathrm{K}^{\prime} \\
\mathrm{Ng} 1\end{array}$ & 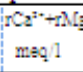 & $\mathrm{rCz}+\mathrm{TMg}$ & SI. & SI, & $\begin{array}{l}\mathrm{HCO}, \\
\mathrm{mg} 1\end{array}$ & $\begin{array}{l}\mathrm{NO}^{-} \\
\mathrm{mg} 1\end{array}$ & $\begin{array}{l}\mathrm{SO}^{3-2} \\
\mathrm{mg} 1\end{array}$ & $\begin{array}{l}\mathrm{Cl}^{-} \\
\mathrm{mg} 1\end{array}$ \\
\hline \multirow{15}{*}{ Ain Zubia } & 0.0085 & 15 & 1050 & 7.03 & 625 & 85.4 & 20.4 & 1691 & 0.92 & 17.83 & 594 & 2539 & -0.069 & -0.716 & 311 & 75 & 24 & 223 \\
\hline & 0.008 & 76 & 7062 & 705 & -692 & 927 & $212^{2}$ & $78.8^{\circ}$ & $1-121$ & $20011^{-1}$ & 637 & 2652 & 0.103 & M141 & 338 & $75^{-1}$ & $43^{-1}$ & $34 Y$ \\
\hline & 6.0007 & 17 & 7105 & $714^{\prime}$ & -658 & 7032 & $254^{2}$ & $212^{-1}$ & 152 & $25.72^{2}$ & $724^{-1}$ & 2464 & $=0.14^{-1}$ & $7823^{\circ}$ & 380 & $76^{-1}$ & $78^{\circ}$ & 213 \\
\hline & $\gamma .0092$ & 73 & 986 & 6.87 & 587 & 7009 & $242^{-}$ & $26 \mathrm{Y}^{-}$ & 1017 & $27, T^{\prime}$ & 7.446 & 2798 & -0.123 & T319 & 392 & 8.8 & 19 & 371 \\
\hline & $\gamma 0135$ & TI & 796 & 687 & 462 & 39. & $184^{-}$ & 129 & $8.03^{-1}$ & $1295^{-1}$ & $-4493^{-1}$ & $19688^{\circ}$ & 0.032 & $20269^{\circ}$ & 2220 & 8.8 & $m^{-}$ & 379 \\
\hline & 0.013 & 115 & 872 & 7.02 & 519 & 612 & 193 & 153 & 0.08 & 1538 & 4642 & 1923 & -0.044 & -0.436 & 229 & $1 \overline{2} 2$ & 351 & 37.7 \\
\hline & r.0008 & 163 & $-1026^{-1}$ & 7 & 611 & 968.8 & 225 & $22 \%$ & $205^{\circ}$ & $2413^{-}$ & 6.832 & 269 & 0.119 & $9371^{-}$ & 352 & 258 & 321 & 355 \\
\hline & 6007 & 173 & $-115 \%$ & $7.76^{\circ}$ & 685 & $112 \%$ & 267 & 28.80 & $232^{-}$ & $31-21$ & 7.796 & 2548 & 0.148 & $-203^{-1}$ & $378^{-1}$ & $1780^{\circ}$ & $83^{-1}$ & 308 \\
\hline & 700086 & 1753 & 879 & 6.78 & 523 & 116.7 & 246 & -33.89 & 239 & 3628 & 7848 & 2877 & -0.15 & $=1892^{-}$ & 392 & $221^{1}$ & 8.0 & 298 \\
\hline & 60125 & 703 & 842 & $68^{-}$ & 501 & $98.4^{-1}$ & 205 & 2298 & 129 & 2427 & 6397 & 2911 & 0.103 & $=7085^{-}$ & $291^{-1}$ & $148^{\prime}$ & $79^{-1}$ & 345 \\
\hline & 0.015 & 105 & 764 & 695 & 453 & $629^{-}$ & 191 & 13.89 & 0.12 & 1401 & $471^{1}$ & 1997 & .0 .04 & $-0392^{-}$ & 187 & $2611^{-1}$ & 151 & 201 \\
\hline & 8015 & 125 & $853^{-1}$ & 701 & 308 & 685 & $20 \mathrm{Y}$ & 191 & 615 & 1925 & $5072^{-1}$ & 2067 & 20.048 & $-8.491^{-1}$ & 218 & $25]^{-1}$ & 332 & -173 \\
\hline & 80.0077 & 795 & $1784^{-}$ & $763^{-1}$ & 643 & 972 & $255^{\circ}$ & 28.78 & 177 & 3131 & 6.784 & 2308 & 20.107 & $=1284^{\prime}$ & $357^{-1}$ & उ1\% & $2 \mathrm{II}^{1}$ & 152 \\
\hline & -0.0073 & 18 & $1872^{-}$ & 7.71 & 638 & 1069 & 25.8 & 359 & 225 & 36.15 & 7459 & 2315 & 20.158 & $-2084^{-1}$ & $387^{-1}$ & $22 Y^{-1}$ & 2.1 & 149 \\
\hline & 0.0073 & 785 & $m m^{-}$ & $7.62^{-}$ & 665 & 1253 & 263 & 38.8 & $281^{-1}$ & 4161 & 8.317 & $28889^{\circ}$ & -0.195 & $-265^{-}$ & $401^{-}$ & $3 \mathrm{~m}$ & 25 & $-166^{-}$ \\
\hline Ninimum & 0.007 & 10.5 & 764 & 6.78 & 455 & 59.7 & 18.4 & 129 & 0.03 & 1293 & 449 & 193 & -0.2 & -2.63 & 187 & 189 & 1.1 & 149 \\
\hline xcasing & -0.013 & $185^{-}$ & 7557 & $7: 12^{2}$ & 689 & 7255 & 26.7 & -58.8 & $288 I^{-}$ & $4105^{\circ}$ & $8 \times I^{-1}$ & "YY厂 & $=20752$ & $=03^{-1}$ & $-401^{-1}$ & "3IY' & 55.7 & $-3 t 77$ \\
\hline Averrags: & -0.0098 & 1457 & 9763 & 697 & 58112 & $93: 20$ & 2253 & 23.64 & 1323 & 2496 & $631^{-}$ & $2,4 \gamma^{-}$ & $r 11$ & -13 & 322 & 16.62 & $12173^{-}$ & -2682 \\
\hline $5 \mathrm{x}$ & 0.00028 & $292^{\circ}$ & $132^{-}$ & 0.101 & 7858 & -21123 & $286^{6}$ & 797 & $695^{\circ}$ & $8.81^{-1}$ & $\mathrm{~T} 28^{-}$ & $\gamma 34$ & $605^{-1}$ & 0.72 & $748^{-1}$ & 9.625 & $1228^{\circ}$ & 8.78 \\
\hline$\vec{v}$ & $0.282^{-1}$ & $\mathrm{~V}_{2 O \mathrm{I}}$ & 0.133 & -0.012 & v.1.155 & 0123 & 6.125 & $0.33^{-}$ & $v /{ }^{\prime}$ & 0.35 & $-v .196$ & $-0.138 y^{-1}$ & $=\sqrt{2}+T$ & $=056^{\circ}$ & $\sqrt{25}$ & w58 & ${ }^{2-01}$ & -032 \\
\hline $\mathrm{Cr} \%$ & 28.4 & 201 & 135 & 14 & 135 & 22.76 & 1267 & 33.72 & 70.53 & 3531 & 196 & 13.76 & -471 & $-56.15^{\circ}$ & 232 & 579 & 10084 & 327 \\
\hline
\end{tabular}


Describe and Statistical Evaluation of Hydrochemical Data of Karst Phenomena in Jordan:

Table 3. Physical and chemical analyses and statistical parameters of the Ain Zgaeg spring

\begin{tabular}{|c|c|c|c|c|c|c|c|c|c|c|c|c|c|c|c|c|c|c|}
\hline $\begin{array}{l}\text { Spring } \\
\text { Nums }\end{array}$ & $\begin{array}{l}Q \\
m^{2} / s\end{array}$ & ${ }^{\mathrm{T}}$ & $\begin{array}{l}\text { EC } \\
\text { us } m\end{array}$ & $\begin{array}{l}\mathrm{pH} \\
\text { unit }\end{array}$ & $\begin{array}{l}\mathrm{DDS} \\
\mathrm{mg} 1\end{array}$ & $\begin{array}{l}\mathrm{Cz}: \\
\mathrm{mg} 1\end{array}$ & $\begin{array}{l}\mathrm{Mg} \mathrm{g}^{+} \\
\mathrm{mg} 1\end{array}$ & $\begin{array}{l}\mathrm{Nz}^{*} \\
\mathrm{mg} 1\end{array}$ & $\begin{array}{l}\mathrm{K}^{*} \\
\mathrm{mg} 1\end{array}$ & $\begin{array}{l}\mathrm{Nz}^{+}+\mathrm{K}^{\circ} \\
\mathrm{mg} 1\end{array}$ & $\begin{array}{l}\mathrm{Cz}^{2^{*}+\mathrm{M} \mathrm{Mg}^{*}} \\
\operatorname{maq} / 1\end{array}$ & $\mathrm{rCz}^{3+} \mathrm{rMg}^{3-}$ & SI. & SI, & $\begin{array}{l}\mathrm{HCO}^{-} \\
\mathrm{mg} 1\end{array}$ & $\begin{array}{l}\mathrm{NO}_{3} \\
\mathrm{mg} 1\end{array}$ & $\begin{array}{l}\mathrm{SO}_{4}^{3-} \\
\mathrm{mg} 1\end{array}$ & $\begin{array}{l}\mathrm{Cl}^{-} \\
\mathrm{mg} 1\end{array}$ \\
\hline \multirow{15}{*}{ Ain $z$ gag } & 0.01 & 14 & 995 & 696 & 592 & 88.4 & 302 & 1688 & 1.84 & 18.72 & 6.896 & 1.775 & -0.074 & -1.146 & 300 & 22.1 & 13 & 190 \\
\hline & $-80099^{-1}$ & $\mathrm{Y}^{-}$ & $-1016^{-}$ & 696 & $605^{-}$ & $954^{-}$ & 309 & $18 \gamma^{-}$ & $185^{-}$ & -1985 & $7203^{-1}$ & T.835' & 20084 & $-1326^{-}$ & $-310^{-}$ & 228 & $311^{\prime}$ & $23 \%$ \\
\hline & $-0.005^{-1}$ & 19 & "m1m2- & 716 & $662^{-}$ & 1214 & $35 \%$ & $256^{-}$ & 245 & $28.05^{\prime}$ & $89966^{-1}$ & $2062^{-}$ & $=0.14^{-1}$ & $-2568^{-1}$ & 355 & 163 & 67 & 222 \\
\hline & $0.012^{-}$ & 135 & $11162^{-}$ & 69 & $692^{-}$ & $7064^{\prime}$ & 388 & $303^{-}$ & 111 & $31-41$ & $8502-$ & T.663' & 0.128 & $-2546^{-}$ & $33 \mathrm{Y}^{-1}$ & $Y 47$ & $18 \%$ & $43 Y^{-}$ \\
\hline & 8.018 & 15 & $706^{-}$ & 69 & $420^{\circ}$ & $599^{-}$ & $223^{-1}$ & $\mathrm{~m}^{2}$ & $0.73^{-1}$ & $1193^{-1}$ & $4854^{--}$ & T.25 & $=0.025$ & 70258 & 253 & 147 & To & $4 S Y$ \\
\hline & 0.017 & 11 & 739 & & $440^{-}$ & $654^{-1}$ & 289 & 149 & $091^{-1}$ & $\overline{15} 8 \mathrm{~B}$ & 5.642 & 1372 & -0.035 & -0514 & 263 & 20.6 & 351 & 391 \\
\hline & 601 & 18 & $1028^{-}$ & 701 & $-612^{-}$ & $-654^{-}$ & 331 & $254^{-}$ & 773 & 25.13 & $7484^{-}$ & $1.748^{-1}$ & 20084 & $-1432^{-}$ & $321^{-}$ & $22 \mathrm{I}^{-}$ & $12 Y$ & $380^{\circ}$ \\
\hline & $0.0075^{-}$ & 19 & $1053^{-}$ & 689 & $627^{-}$ & 1038 & 333 & $-2832^{-}$ & $22 \mathrm{Y}^{-}$ & 3033 & $802^{--}$ & T9: & 20115 & -196" & $345^{-}$ & $209^{\circ}$ & 301 & 374 \\
\hline & rri- & $145^{-}$ & $1067^{-}$ & 677 & $635^{-}$ & T119 & 374 & $269^{-}$ & $238^{\circ}$ & 2928 & $8.661^{-}$ & $1814^{-1}$ & 2.129 & -248 & $341^{-}$ & $26 \mathrm{I}^{-}$ & $29 \mathrm{Y}^{\circ}$ & 293 \\
\hline & $60131^{-1}$ & $125^{-}$ & 873 & 75 & $-519^{-}$ & $85 \%$ & 294 & $205^{-}$ & $789^{-1}$ & 2239 & $6.396^{-}$ & $1768^{-}$ & 20069 & -1056 & 289 & 152 & $55^{-}$ & $413^{-}$ \\
\hline & 0.017 & 115 & 685 & 734 & $408^{-1}$ & 582 & 211 & $154^{-}$ & 167 & 17.07 & 4641 & 1673 & -0.013 & $-0.141^{-}$ & 238 & 169 & $82^{-}$ & $42-4$ \\
\hline & $\gamma .016$ & '125' & $" 719^{-}$ & 722 & $-428^{-}$ & 68.6 & $244^{-}$ & 175 & $058^{-}$ & $18.08^{-}$ & $5.451^{-}$ & $-17905^{-1}$ & 70.019 & $D 233$ & $243^{-}$ & 1925 & 31 & $29-4$ \\
\hline & $0.0094^{-1}$ & $173^{\circ}$ & 7006 & 71 & 599 & 893 & 325 & 289 & $132^{-}$ & 3042 & 7.13 & 1666 & $-20094^{-1}$ & -1362 & $358^{\circ}$ & $28^{-1}$ & 79 & 279 \\
\hline & $\gamma .000$ & $195^{\circ}$ & $7040^{\circ}$ & 7.7 & $619^{-}$ & 1034 & 352 & 318 & $789^{-1}$ & $35.69^{-}$ & $8056^{-}$ & $1.781^{-1}$ & $20176^{-1}$ & -2091 & $351^{-}$ & $389^{-}$ & 89 & 395 \\
\hline & $\gamma 0008^{-1}$ & $205^{-}$ & $7089^{\circ}$ & 689 & $628^{-}$ & 11139 & $36 Y^{-1}$ & 3389 & $2 \gamma g^{-}$ & 3598 & 8.654 & 9913 & $-0.145^{-1}$ & -2.685 & $377^{-}$ & $83^{--}$ & $215^{-}$ & 36.4 \\
\hline Minimum & 0.0075 & 11 & 685 & 6.77 & 408 & 58.2 & 21.1 & 11.2 & 0.58 & 1193 & 464 & 137 & -0.145 & -2.685 & 238 & 28 & 1.3 & 19 \\
\hline Naximum & vorys- & 203 & mider & $T T T^{\prime}$ & $69 \mathrm{~T}^{-1}$ & $725 \times$ & $-38.8^{-1}$ & 359 & $275^{-}$ & $35 y 8^{-}$ & $g-$ & $21^{-1}$ & $=0.013$ & $=25.145$ & 377 & $26.1^{-1}$ & $35 \mathrm{II}^{-1}$ & $25]^{-1}$ \\
\hline Averag & $00116^{-1}$ & $155^{-1}$ & $y_{52}=$ & 709 & 3671 & 9114 & $5 \Gamma 5$ & $229^{-1}$ & $-1.36^{-}$ & $296-$ & 7.12 & $7=70^{-1}$ & "2vovgy & $1-465$ & $352^{-}$ & 16.28 & {$\left[47 T^{-}\right.$} & $32 \mathrm{I}^{-}$ \\
\hline $2 x$ & $0.0037^{-}$ & 329 & $1655^{-1}$ & VI6 & y.r & 2028 & $5366^{\circ}$ & $-71^{-1}$ & $V_{38}$ & 737 & $-1-43^{-1}$ & $v .10^{-}$ & wors & vor- & $289^{-1}$ & $-687^{-1}$ & ${ }^{-I I X-1}$ & $8.16^{-}$ \\
\hline $\mathrm{CH}^{-}$ & $031 \%$ & $0: 21^{-}$ & v.17/ & 2030 & ס:I7I & 02215 & VIT/2 & ${ }^{0}-3 \mathrm{I}^{-}$ & $0351^{-}$ & $\sqrt{3}$ & v2vI' & vog- & $2 \sqrt{5} 34$ & $=0.62^{-}$ & $v .174^{-}$ & $0 \times 418$ & $07801^{-1}$ & $\mathrm{O}=2 \mathrm{~S}^{-}$ \\
\hline $6 \%$ & 317 & -2113 & Mr & $-3.6^{-}$ & $1771^{-}$ & $-523^{-}$ & 172 & 31 & 351 & $30^{-1}$ & $-2011^{-1}$ & $\gamma^{-1}$ & -54 & $-62^{-}$ & 144 & 418 & 801 & 24 \\
\hline
\end{tabular}

Table 4. Physical and chemical analyses and statistical parameters of the Al-Kura District wells water.

\begin{tabular}{|c|c|c|c|c|c|c|c|c|c|c|c|c|c|c|c|c|c|c|}
\hline Well Name & $\begin{array}{l}Q \\
m^{2} / s\end{array}$ & ${ }^{\circ} \mathrm{C}$ & $\begin{array}{l}\mathrm{BC} \\
\mathrm{wa} \mathrm{cm}\end{array}$ & $\begin{array}{l}\text { pH } \\
\text { Unit }\end{array}$ & $\begin{array}{l}\text { TDS } \\
\mathrm{mg} 1\end{array}$ & $\begin{array}{l}\mathrm{Cg} \\
\mathrm{mg} 1\end{array}$ & $\begin{array}{l}\mathrm{Mg} \\
\mathrm{mg} 1\end{array}$ & $\begin{array}{l}\mathrm{Na}^{\circ} \\
\mathrm{mg} 1\end{array}$ & $\begin{array}{l}\mathrm{K}^{\circ} \\
\mathrm{mg} 1\end{array}$ & $\begin{array}{l}z^{2}+\mathrm{K}^{\circ} \\
\operatorname{Mgg} 1\end{array}$ & $\begin{array}{l}\mathrm{z}^{2}+\mathrm{n} \mathrm{Ng} \\
\operatorname{maq} 1\end{array}$ & $\mathrm{Cz} z^{* *} / \mathrm{Mgg}^{*}$ & SI. & SI. & $\begin{array}{l}\mathrm{HCO}_{1} \\
\mathrm{mg} 1\end{array}$ & $\begin{array}{l}\mathrm{NO}_{2} \\
\mathrm{mg} 1\end{array}$ & $\begin{array}{l}\mathrm{SO}_{4}=- \\
\mathrm{mg} 1\end{array}$ & $\begin{array}{l}\mathrm{Cl} \\
\mathrm{mg} 1\end{array}$ \\
\hline \multirow{3}{*}{ Beit Idis Well } & 0.042 & 17 & 769 & 7.7 & 458 & 90 & 28.7 & 17 & 2 & 19 & 6852 & 1902 & 20.066 & -0968 & 382 & 16 & 17 & 33 \\
\hline & vora & $78^{-}$ & $820^{-}$ & 778 & 285 & 90 & $29 Y_{2}$ & $\mathrm{TT}^{\mathrm{T}}$ & $16^{-}$ & 78.6 & 6.895 & $787^{-1}$ & 0005 & ovg3t & $382^{-}$ & ${ }^{-} \mathrm{CI}^{-}$ & 165 & $2 y^{-}$ \\
\hline & $-0.043^{-}$ & 775 & 827 & 79 & -492 & $90^{\circ}$ & 275 & 17 & $1 \%$ & -18.6 & 6.756 & $7984^{-1}$ & $\because 0872^{-}$ & "IVIS' & -382 & $162^{-1}$ & 16 & $29^{\circ}$ \\
\hline \multirow{4}{*}{ JudytaWall1 } & vover & 155 & $783^{-}$ & 74 & $2866^{-}$ & 85 & 282 & $255^{-}$ & -3 & -28 & $6 \times 6 \mathrm{I}^{-}$ & I'T85'- & 20005 & 725906 & $-552^{-}$ & $-3 y^{--}$ & -18 & $r I^{-}$ \\
\hline & vos & 165 & $7 y 8^{-1}$ & 728 & 275 & 85 & $282^{-}$ & $27^{-}$ & $0{ }^{-}$ & $271^{-1}$ & 6578 & rysy"- & 00005 & wogay & $35 y^{-}$ & $2 r y$ & $v^{-}$ & 25 \\
\hline & ${ }^{-0} 0 x x^{-}$ & 765 & 781 & $7726^{-}$ & -465 & $90^{-}$ & $288^{-}$ & 27 & $v$ & $27 \mathrm{I}^{-}$ & 6867 & $78 y 5$ & "zvos" & $=1=575^{-}$ & $35 y-$ & $2 \mathrm{TI}^{-1}$ & $\gamma^{-}$ & $-40^{-1}$ \\
\hline & $-07555^{-1}$ & 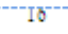 & 816 & 74 & $480^{-}$ & $87^{-}$ & $28 \div$ & 25 & 33 & $28-3$ & -6.653 & $7887 \%$ & -5007 & "Ivos & -352 & $-32^{--}$ & $788^{-1}$ & $42^{-1}$ \\
\hline \multirow{5}{*}{ Judyta Wel12 } & $-v 050$ & $76^{-1}$ & $7855^{-}$ & $722^{-}$ & $2677^{-1}$ & 88 & 293 & $r I^{-}$ & $-3^{--}$ & $-2 \mathrm{~S}^{-}$ & $6802^{-}$ & 'rysI' & 20.072 & $=1076$ & $362^{-}$ & $-5 \Gamma^{-}$ & $-16^{--}$ & $3 y^{-}$ \\
\hline & $-0.082^{-}$ & 145 & $71 y^{-}$ & ${ }^{7} 7.54^{-}$ & -428 & 79 & 78 & 27 & vis & $27 \mathrm{I}^{-}$ & 6228 & 'mer' & ":ov52" & $=07770^{\circ}$ & 325 & 327 & $\sigma^{-1}$ & $-42^{-1}$ \\
\hline & 07047 & 165 & $729^{\circ}$ & 787 & $-432^{-}$ & $\mathrm{Yo}^{-}$ & $r 9^{-1}$ & 28 & $\mathrm{TI}^{-1}$ & $29{ }^{-1}$ & 6877 & 78882 & "20.073 & -rvgge & $380^{\circ}$ & 23 & $\mathrm{TI}^{-}$ & $4 \mathrm{I}^{-1}$ \\
\hline & vovs & -15 & $764^{-1}$ & 7.18 & $255^{-}$ & $\mathrm{yI}^{-}$ & 273 & $277^{-}$ & o. & $27 T$ & $-6554^{-}$ & IXOS & $2505 y$ & 725852 & $-349^{-}$ & 3277 & $\gamma^{-}$ & $-44^{-}$ \\
\hline & - $0058^{-}$ & $" 17{ }^{-1}$ & 7855 & ${ }^{-7} 724^{-}$ & -467 & $-88^{-1}$ & $28 \mathrm{I}^{-}$ & 22 & $2 \%$ & $22^{-2} 6^{-1}$ & 6.705 & 'Tryys" & $=0079$ & $=1750^{\circ}$ & $362^{-}$ & 313 & ${ }^{2} 7^{-}$ & $39^{-}$ \\
\hline 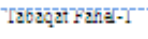 & $-07028^{-}$ & $17 / 5$ & $y_{5} 9^{-}$ & $773 y^{-1}$ & $571^{-}$ & IOT & $-30^{-1}$ & -37 & " & $-5 I^{--}$ & 7559 & $2006 T^{-1}$ & $-20 v y 7^{-}$ & "rayg & $-410^{-1}$ & 15 & 55 & $66^{-}$ \\
\hline \multirow{4}{*}{ Tabaqut Fuhel-3 } & vorr & I75 & yygz"- & $777^{-}$ & $386^{-}$ & -503 & $3 \Gamma$ & $47^{-}$ & 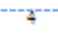 & $3 r^{-}$ & "7oys- & $2008^{-1}$ & ?Joy7 & $25 x y$ & $\rightarrow\left[7^{-}\right.$ & $-r 4^{-}$ & $3 r$ & $r 0^{-}$ \\
\hline & $v 057^{-}$ & 75 & $954^{-}$ & $7 \times 2^{-1}$ & 568 & $86-$ & 278 & $84^{-}$ & $-z 6^{-}$ & $28.6-$ & 6378 & $-5876^{-1}$ & 20.066 & "2Jys" & $355^{-}$ & 285 & 53 & $8 \mathrm{ST}^{--}$ \\
\hline & - $0.063^{-}$ & 155 & $966-$ & $-7-46^{-}$ & 575 & 82 & 279 & $34^{-}$ & -46 & $-48.6^{-}$ & 6387 & T.781- & $=0759$ & $=078 x 2^{-}$ & $35 r^{-}$ & 28.8 & $538^{-}$ & $-85^{-}$ \\
\hline & 0025 & 185 & ygyz" & 7775 & $386^{-}$ & $-503^{-}$ & 291 & $47^{-}$ & $39^{-}$ & $30 y$ & $7533^{-}$ & 2540 & $2510 \Gamma^{-}$ & 7584 & $757^{-}$ & $-13: T^{-}$ & $3 r$ & $r 0^{-}$ \\
\hline 'labāọat Fahe: & "vos" & $" 788^{-1}$ & -9x4"- & $7770^{-1}$ & 562 & $7003^{-1}$ & $" 3 v^{-}$ & $\mathrm{CI}^{-}$ & -3 & 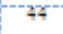 & $7.0088^{-1}$ & $208 I^{-}$ & roosy & 7364 & $273^{-}$ & 765 & 35 & 64 \\
\hline Tabaqut Fahel-6" & - vojos' & 775 & 897 & $-77^{-}$ & -537 & 98 & $302^{-}$ & $3 r$ & -3 & $-20^{-1}$ & 7375 & $7988^{-}$ & $=0709 \sigma^{-1}$ & $=1-485^{-}$ & -400 & 17 & $30^{--}$ & $56-$ \\
\hline 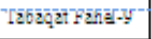 & rovey & $-18^{-1}$ & $y 73$ & 7755 & 579 & Ior & $-51^{-1}$ & $-3 z^{--}$ & - & $-48^{--}$ & $7.671^{-1}$ & 1995 & "Jvyya & 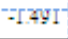 & $420^{\circ}$ & 16 & $57^{-}$ & $70^{-1}$ \\
\hline Minimum & 0.024 & 145 & 719 & 7.14 & 428 & 79 & 275 & 17 & 0.1 & 18.6 & 625 & 1.711 & -0.101 & -1.549 & 345 & 13.7 & 0 & 28 \\
\hline Mzximum & -0.082 & 18.5 & -gys" & $-7 y^{-1}$ & 586 & $703^{-}$ & $3111^{-1}$ & 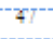 & $-76^{-}$ & $-5 r^{-}$ & ${ }^{-} 7 T^{-}$ & 2796 & 20054 & 207776 & $2720^{-}$ & $54^{-1}$ & $-538^{-}$ & $-85^{--}$ \\
\hline Average & 0.0372 & 76.06 & 85185 & $75^{-}$ & 5871 & 911 & 289 & $31 \%$ & 249 & 3424 & 69 & $191^{-1}$ & $-0.076^{-1}$ & 9192 & 3778 & $-23 v 2$ & $222^{-}$ & 5723 \\
\hline $2 x^{--}$ & 000158 & $716^{-1}$ & $\vartheta_{5}: 73^{-}$ & $02233^{\circ}$ & 5378 & $79^{-1}$ & 11 & $\mathrm{TI}^{-1}$ & 156 & 1198 & $0.43^{-1}$ & $0.112^{-3}$ & 0.015 & $\gamma 26^{-}$ & 2682 & $7.6 T^{-1}$ & $16.56^{-}$ & 17.68 \\
\hline $\mathrm{Cv}^{-1}$ & visyy & 0.07 & ${ }^{-} \mathrm{HI}^{-1}$ & - & $\mathrm{O}^{-} \mathrm{SI}^{-}$ & 009 & $084^{-}$ & 635 & 8.63 & 055 & 8007 & $0.06^{-1}$ & 0197 & -025 & 8071 & $0-333$ & 0.77 & vis4 \\
\hline Cry\%" & $-33^{-} 49^{-}$ & $6 y 7^{-1}$ & ${ }^{-} \mathrm{CI}^{-}$ & $3705^{-1}$ & "YI" & 87 & $3.78^{-}$ & 3481 & 327 & $35^{--}$ & 685 & $586^{-1}$ & $-19^{-74}$ & -25 & $7 y^{-1}$ & $3352^{-}$ & ${ }^{7} 77^{-1}$ & 5457 \\
\hline
\end{tabular}


Describe and Statistical Evaluation of Hydrochemical Data of Karst Phenomena in Jordan:

Table 5. Comparison of the coefficients for chemical and physical variations of Al-Dhaher Cave Spring with Ain Zubia, Ain Zgaeg, and Al-Kura wells

\begin{tabular}{|c|c|c|c|c|c|c|c|c|c|}
\hline Variable & $\begin{array}{l}\text { Al-Dhaher } \\
\text { Cave Spring }\end{array}$ & $\begin{array}{c}\text { Ain } \\
\text { Zubia }\end{array}$ & $\begin{array}{c}\text { Ain } \\
Z_{\text {gaeg }}\end{array}$ & $\begin{array}{c}\text { Al-Kura } \\
\text { wells }\end{array}$ & $\min$ & $\max$ & average & $\sigma x$ & $\mathrm{C} \% \%$ \\
\hline \multicolumn{10}{|c|}{ Chemical Variables } \\
\hline $\mathrm{Ca}^{--}(\mathrm{mg})$ & 6956 & 93293 & 91.14 & 91.05 & 6956 & 93.293 & 8626 & 112 & 13 \\
\hline $\mathrm{Mg}=(\mathrm{mgl})$ & 273 & 22533 & 31287 & 28.895 & 22533 & 31287 & 2751 & 3.7 & 134 \\
\hline $\mathrm{Na}^{-}(\mathrm{mgl})$ & 16.86 & 1.657 & 22899 & 31.6 & 1.657 & 316 & 1825 & 126 & 69 \\
\hline $\mathrm{K}^{-}(\mathrm{mg})$ & 0.706 & 1323 & 23.636 & $2485^{-1}$ & 0.706 & 23.636 & 704 & $111^{-1}$ & 158 \\
\hline $\mathrm{rCa}^{2}+\mathrm{rM} \mathrm{g}^{-}(\mathrm{meq} \mathrm{I})$ & 5.717 & 651 & 7.122 & 6921 & 5.717 & 7.122 & 6.57 & 0.62 & 95 \\
\hline $\mathrm{rCa} / \mathrm{rMg}^{2}$ & 1535 & $2486^{-}$ & 1755 & 1908 & 1535 & 2486 & $192^{-}$ & 0.41 & 22 \\
\hline $\mathrm{Si}_{\varepsilon}^{-}$ & -0.053 & -0.105 & -0.084 & -0.076 & -0.105 & -0.053 & -0.1 & 0.02 & -27 \\
\hline $\mathrm{SI}_{i}$ & -0.758 & -128 & -1.465 & -1.1271 & -1.465 & -0.758 & -1.16 & 0.3 & $-26-$ \\
\hline $\mathrm{HCO}_{3}^{-}(\mathrm{mgl})$ & 285 & 3222 & 311867 & -377.75 & $285^{-1}$ & 377.75 & 3242 & $3899^{\circ}$ & 12 \\
\hline $\mathrm{NO}_{3}(\mathrm{mgl})$ & 253 & 16.6193 & $16.439^{\circ}$ & 23.015 & 16.439 & 253 & 20.34 & 45 & 22 \\
\hline $\mathrm{SO}_{4}^{-m}(\mathrm{mg})$ & $1212^{-}$ & 121733 & 14.73 & 22355 & 12173 & 22355 & 1535 & $483^{-1}$ & 32 \\
\hline $\mathrm{Cl}(\mathrm{mgl})$ & 2558 & 2682 & 3408 & 51.45 & 2558 & 51.45 & 3448 & 1192 & 35 \\
\hline \multicolumn{10}{|l|}{ Physical Variables } \\
\hline $\mathrm{Q}\left(\mathrm{m}^{3} / \mathrm{s}\right)$ & 0.0008 & 0.0098 & 0.012 & 0.0472 & 0.0008 & 0.047 & 0.02 & 0.02 & 118 \\
\hline$T\left({ }^{\circ} \mathrm{C}\right)$ & 143 & 1457 & 15.47 & 16.675 & 143 & 16.675 & 1525 & 107 & 7 \\
\hline EC(us cm) & 8054 & 9763 & 9527 & 85185 & 8054 & 997633 & 89656 & 8128 & 9 \\
\hline $\operatorname{TDS}(\mathrm{mg})$ & 4794 & 5812 & 5670 & 507.1 & 4794 & 5812 & 533.69 & 4839 & 9 \\
\hline $\mathrm{pH}$ (unit) & 7216 & 69747 & 7.1 & 7.488 & 6975 & 7.488 & 7.19 & 0.22 & 3 \\
\hline
\end{tabular}

Table 6. Coefficients of variations of Al-Dhaher Cave Spring, Ain Zubia, Ain Zgaeg, and Al-Kura wells comparison with Rock Spring (Jacobson and Langmuir, 1974), Iskrets Spring (Eftimi and Benderev, 2007), and Thomson Spring (Jacobson and Langmuir, 1974).

\begin{tabular}{|c|c|c|c|c|c|c|c|}
\hline Variable & $\begin{array}{l}\text { Al-Dhaher } \\
\text { Cave Spring }\end{array}$ & Ain & $\begin{array}{l}\text { Ain } \\
Z_{\text {gaeg }}\end{array}$ & $\begin{array}{l}\text { AlKura } \\
\text { wells }\end{array}$ & $\begin{array}{l}\text { Rock Spring } \\
\text { Conduit type }\end{array}$ & $\begin{array}{l}\text { Iskrets Spring } \\
\text { Conduit type }\end{array}$ & $\begin{array}{l}\text { Thomson Spring } \\
\text { Diffusive type }\end{array}$ \\
\hline \multicolumn{8}{|c|}{ Chemical Variables } \\
\hline $\mathrm{Ca}^{2-}$ & 18.1 & 23.0 & 223 & 8.7 & 255 & 11.7 & 6.4 \\
\hline $\mathrm{Mg}_{\mathrm{r}}$ & 84 & 127 & 172 & 38 & 276 & 300 & $20^{--}$ \\
\hline $\mathrm{rCa}+\mathrm{MMg}$ & 143 & 196 & 20.1 & 69 & $\cdot$ & 634 & $\because$ \\
\hline $\mathrm{rCa}=7 \mathrm{rMg}^{2-}$ & 99 & 138 & $90^{--}$ & 59 & $\because$ & 282 & $\because$ \\
\hline $\mathrm{SI}_{\varepsilon}$ & 40 & $47.1^{-1}$ & 540 & 197 & 18.7 & 355 & 16.1 \\
\hline $\mathrm{SI}_{i}^{-}$ & 47. & 562 & $620^{--}$ & $230^{-1}$ & $\because$ & 28.8 & $\because$ \\
\hline $\mathrm{HCO}_{3}^{--}$ & 68 & 232 & 144 & $71^{-1}$ & 28.6 & 142 & 27 \\
\hline $\mathrm{NO}_{3}^{--}$ & 278 & 579 & 418 & 333 & 320 & 46.7 & 199 \\
\hline $\mathrm{SO}_{4}$ & 262 & 101 & 80.1 & $741^{-1}$ & $127^{-\cdots}$ & 43,7 & 178 \\
\hline $\mathrm{Cl}^{--}$ & 40.8 & 32.7 & 24 & 344 & 17.7 & 245 & 29 \\
\hline \multicolumn{8}{|c|}{ Physical Variables } \\
\hline $\mathrm{Q}\left(\mathrm{m}^{\mathrm{j}} / \mathrm{s}\right)$ & 43.4 & 28.4 & 31.7 & 335 & 175 & 942 & 263 \\
\hline $\mathrm{T}\left({ }^{\circ} \mathrm{C}\right)$ & 145 & 20.1 & 213 & 70 & 269 & 103 & 14 \\
\hline $\mathrm{pH}$ (unit) & 23 & 14 & 36 & 31 & 17 & 16 & 0.6 \\
\hline
\end{tabular}

